Olden, J.D., Kennard, M.J. \& Pusey, B.J. (2012). A framework for hydrologic classification with a review of methodologies and applications in ecohydrology. Ecohydrology. 5: 503518. DOI: $10.1002 /$ eco.251.

Published version on Journal website available at:

http://dx.doi.org/10.1002/eco.251 


\section{A framework for hydrologic classification with a review of methodologies and applications in ecohydrology}

3

11 Hydrologic classification is one of the most widely applied tasks in ecohydrology. During the

12 last two decades considerable effort has gone into analysis and development of methodological

13 approaches to hydrologic classification. We review the process of hydrologic classification,

14 differentiating between an approach based on deductive reasoning using environmental

15 regionalization, hydrologic regionalization and environmental classification whereby

Julian D. Olden, ${ }^{1 *}$ Mark J. Kennard, ${ }^{2}$ Bradley J. Pusey ${ }^{2}$

${ }^{1}$ School of Aquatic and Fishery Sciences, University of Washington, Box 355020, Seattle, WA 98195, United States

${ }^{2}$ Tropical Rivers and Coastal Knowledge, National Environmental Research Program Northern Australia Hub and Australian Rivers Institute, Griffith University, Nathan, Queensland, 4111, Australia

\section{ABSTRACT} environmental variables assumed to be key determinants of hydrology are analyzed, and one based on inductive reasoning using streamflow classification whereby hydrologic data is analyzed directly. We explore past applications in ecohydrology highlighting the utility of classifications in the extrapolation of hydrologic information across sparsely gauged landscapes, the description of spatial patterns in hydrologic variability, aiding water resource management, and in the identification and prioritization of conservation areas. We introduce an overarching methodological framework that depicts critical components of the classification process and summarize important advantages and disadvantages of commonly used statistical approaches to characterize and predict hydrologic classes. Our hope is that researchers and managers will be better informed when having to make decisions regarding the selection and proper implementation of methods for hydrologic classification in the future.

KEY WORDS: dams; flow regime; environmental flow; river regulation; hydrologic metric 
INTRODUCTION

30 Hydrologic classification is the process of systematically arranging streams or rivers into groups

31 that are most similar with respect to the characteristics of their flow regime. The classification of

32 flow regimes continues to play an important role in ecohydrology as a means to understand

33 riverine flow variability (e.g. Mosley, 1981; Haines et al., 1988; Poff, 1996; Harris et al., 2000;

34 Snelder et al., 2009a), explore the influence of streamflow on biological communities and

35 ecological processes (e.g. Jowett and Duncan, 1990; Poff and Allan, 1995; Snelder et al., 2004;

36 Kennard et al., 2007), aid hydrologic modeling in regionalization analyses (e.g. Tasker, 1982;

37 Nathan and McMahon, 1990; Wagener et al., 2007), inventory hydrologic types for water

38 resource management (e.g. Snelder and Biggs, 2002; Wolock et al., 2004; Arthington et al.,

39 2006), and prioritize conservation efforts for freshwater ecosystems (e.g. Nei et al., 2007;

40 Snelder et al., 2007). The flow regime is a key determinant of freshwater biodiversity patterns

41 and ecological processes (Poff et al., 1997; Bunn and Arthington, 2002). Hydrologic

42 classification has therefore been identified as a critical process in environmental flow

43 assessments by providing a spatially explicit understanding of how much and when flow regimes

44 vary among rivers and regions (Kennard et al., 2010b; Poff et al., 2010). Consequently,

45 hydrologic classification is viewed as both an organizing framework and scientific tool for river

46 research and management.

$47 \quad$ Challenged by the need to quantify flow similarities among rivers and map their distribution

48 across the landscape, ecohydrologists have turned to a bewildering (and expanding) array of

49 protocols using an equally diverse set of statistical approaches to conduct their hydrologic

50 classification. As a result, several groups of methods are in use, and to-date no single approach

51 has demonstrated universally accepted results. This is not entirely surprising given that despite

52 the growing use of hydrologic classification in ecohydrology, little guidance and no synthesis on

53 this topic has been published in the literature, and the purposes for conducting a classification

54 vary greatly. Herein, we provide a systematic review of the process of hydrologic classification

55 by (i) reviewing two broad classification approaches according to deductive reasoning using

56 environmental regionalization, hydrologic regionalization and environmental classification

57 whereby environmental variables assumed to be key determinants of hydrology are analyzed,

58 and inductive reasoning using streamflow classification whereby hydrologic data is analyzed 
directly; (ii) exploring past applications in ecohydrology; (iii) introducing a unifying methodological framework that depicts critical components of the classification process; and (iv) summarizing important advantages and disadvantages of commonly used statistical approaches to characterize and predict hydrologic classes. The intention of our study is to inform ecohydrologists about the critical elements of hydrologic classification, including a discussion of the important considerations and techniques available to them.

\section{APPROACHES TO HYDROLOGIC CLASSIFICATION}

Hydrologic classification refers to a broad suite of methods that seek to characterize similarities in hydrologic properties among locations. We recognize two broad approaches that either classify locations according to attributes describing those aspects of the environment assumed to influence streamflow (the deductive approach consisting of environmental regionalization, hydrologic regionalization and environmental classification) and those that classify the emergent properties of the discharge time series (the inductive approach or streamflow classification) (Figure 1).

Deductive approaches to hydrologic classification are commonly used when the objective is to describe and quantify the spatial variation in flow regime attributes across broad spatial scales but where the availability of gauged or modeled hydrologic data is scarce or absent. The availability of high quality hydrologically-relevant environmental datasets (e.g. describing climate, catchment topography, soils and geology, vegetation and land use) makes deductive reasoning an appealing approach to defining spatial similarities and differences in perceived hydrologic characteristics. There are limits, however, in the particular facets of the flow regime able to be accurately quantified by this approach. Poor data quality (e.g. soil and geology) and limited understanding of hydrologic processes (e.g. groundwater-surface water connectivity) in many regions means that the ability to accurately characterize spatial variation in low flow magnitude and duration (for example) is often precluded using deductive environmental classifications.

Inductive approaches to hydrologic classification are typically conducted using various attributes describing different components of the riverine flow regime. This approach has the advantage of being based on direct measures of hydrology (rather than indirect environmental 
surrogates for hydrology) but has a number of limitations including the often limited spatial coverage of stream gauges within the river network and the notoriously variable quality and quantity of discharge data available for each gauge (Kennard et al., 2010a). Key characteristics and examples of deductive and inductive approaches to hydrologic classification are presented in more detail below.

\section{Deductive Approaches}

\section{Environmental regionalization}

Environmental regionalization is commonly used to provide a spatial representation of similarity, whereby contiguous or non-contiguous regions are considered homogeneous with respect to certain environmental characteristics at a particular scale (Bryce and Clarke, 1996; Loveland and Merchant, 2004). This approach is often developed because it is not necessarily reliant on empirical flow data and can be carried out using existing maps and spatial databases (e.g. Bailey, 1996; Omernik, 2004). Geographically contiguous regions, such as river basins, have been used to group streams assumed to have similar hydrologic characteristics (Table 1), although there is ample evidence that flow regimes vary greatly within river basins (Poff et al., 2006; Kennard et al., 2010b). Despite the appeal and advantages of estimating hydrologic similarity based on an environmental regionalization approach, streams and rivers within the same region (whether contiguous such as river basins or non-contiguous such as hydro-regions) are not guaranteed to be hydrologically homogenous. Kennard et al. (2010b) showed that flow regime classification of stream gauges in Australia did not correspond well to membership based on a suite of biophysical classifications schemes, including major drainage basins, freshwater ecoregions, and Köppen climate divisions. Similarly, Carlisle et al. (2010) found that the environmental drivers of streamflow vary substantially even within relatively homogenous hydrologic regions of the United States.

\section{Hydrologic regionalization}

The regionalization of hydrologic models has a long history of use in attempting to extend insights gained from well-gauged regions to ungauged or sparsely gauged regions or rivers (e.g. Tasker, 1982; Nathan and McMahon, 1990; Vogel et al., 1999; Chiang et al., 2002; Merz and 
119 Bloeschl, 2004; Wagener et al., 2007). The common approach to hydrologic regionalization in

120 ungauged basins is to delineate geographic areas of similar streamflow pattern, use regression to 121 relate catchment environmental characteristics to hydrologic metrics describing the flow regime

122 within these areas, and assess model reliability. Typically, only specific components of the flow 123 regime are included, such as flood and low flow frequency (e.g. Wiltshire, 1986; Nathan and

124 McMahon, 1990; but see Sanborn and Bledsoe, 2006). By dividing a study area into

125 homogeneous groups that are considered to exhibit similar hydrologic characteristics, hydrologic

126 metrics may be extrapolated with more precision, and regionalization models based on

127 catchment characteristics may be used with greater confidence. In addition, some explanatory

128 factors (e.g., orographic effects, geology) are not well represented by continuous variables with

129 monotonic relation to flow, so classification prior to regionalization will likely improve the 130 ability to extrapolate hydrologic characteristics. Often regionalization groupings encompassed

131 geographically contiguous areas (e.g. Mosley, 1981; Hughes, 1987; Wagener et al., 2007).

Environmental classification

134 Environmental classification (also termed environmental domain analysis - Mackey et al., 2007)

135 defines classes based on physical and climatic attributes that are assumed to broadly produce

136 similar hydrological responses in stream systems. This represents a deductive approach to

137 hydrologic classification that is often geographically-independent and depicted by a spatial

138 mosaic of hydrologic types across the landscape (Detenbeck et al., 2000). An advantage of this

139 approach is that it is not reliant on an extensive spatial coverage of stream gauges to characterize

140 flow regimes. Instead, spatially comprehensive environmental datasets are often readily

141 available (e.g. in a Geographic Information System) and suitable to the task. Numerous

142 physical-based or geomorphic classifications of rivers have been conducted, including those

143 based on similar topography, surficial geology and climate (e.g. Kondolf, 1995; Wolock et al.,

144 2004; Buttle, 2006; Abell et al., 2008; Stein et al., 2009; Sawicz et al., 2011), as well as

145 combined hydro-geomorphic typologies (e.g. Snelder and Biggs, 2002; Snelder et al., 2005;

146 Schmitt et al., 2007, reviewed in Kondolf et al., 2003) (Table 1). We discuss two examples

147 below.

148 The concept of hydrologic landscape regions was introduced by Winter (2001) and

149 developed by Wolock et al. (2004) to describe non-contiguous areas for the United States that 
150

151

152

153

154

155

156

157

158

159

160

161

162

163

164

165

166

167

168

169

170

171

172

173

174

175

176

177

178

179

180

reflected aggregated river basins sharing similar environmental factors (e.g. climate, soils, geology, topography) known to influence streamflow. According to this classification, a fundamental hydrologic landscape unit could be defined according to: (a) the movement of surface water, which is controlled by the slopes and permeability of the landscape; (b) the movement of ground water, which is controlled by the hydraulic characteristics of the geologic framework; and (c) atmosphere-water exchange, which is controlled by climate. Using multivariate ordination and cluster analysis, Wolock et al. (2004) assigned membership of nearly 44,000 small (ca. $200 \mathrm{~km}^{2}$ ) watersheds in the United States to 20 hydrologic regions based on similarities in land-surface form, geologic texture, and climate characteristics (Figure 2). The hydrologic landscape region and similar concepts have proven useful in ecohydrology because they are founded on sound physical principles, yet this framework has only rarely been tested against regional hydrologic variables. Santhi et al. (2008) demonstrated that the classification approach has merit in predicting regional variations in baseflow, and Carlisle et al. (2010) found that stratification by hydrologic landscape regions improved models predicting hydrologic metrics from watershed characteristics. By contrast, McManamay et al. (2011) reported that hydrologic landscape regions showed little concordance with the hydrologic classes of Poff (1996; see below) for the continental United States, and explained $<30 \%$ of the overall variability in the hydrologic metrics.

A similar framework is represented by the River Environment Classification (REC) scheme for New Zealand (Snelder and Biggs, 2002). This classification is represented by a mapped hydro-geomorphic topology of rivers based on a combination of watershed climate and topography, which are assumed to be the dominant causes of variation in hydrologic character at a variety of spatial scales (Figure 3). In support of this approach, Snelder et al. (2005) found that the REC explained statistically significant amounts of variation in 13 hydrologic metrics.

Specifying a-priori the boundaries between classes (i.e. a 'top-down' approach to environmental classification) has been criticized (e.g. O’Keefe and Uys, 2000; Stein et al., 2009) as it assumes all possible classes are already known. A 'bottom-up' approach to the environmental classification may be preferable as it results in classes that are an emergent property of the data and reflect the shared similarities of key attributes (Mackey et al., 2007); assuming that the modeled data is representative of the total variation that exists. Although there are still subjective choices as to environmental attributes, weightings, classificatory strategy and 
181 numbers of groups to include in the classification process, these decisions are explicit and 182 therefore transparent and repeatable (Stein et al., 2009).

183 Classifications based on environmental deduction, including REC, are common in the 184 literature because topography, surficial geology and climate are assumed to control hydrological 185 processes (e.g. precipitation, storage and release of water by watersheds). However, they do not 186 necessarily reflect only hydrological variation because they usually encompass more general principles concerning the causes of physical variation in streams and rivers (Snelder et al., 2005;

188 Carlisle et al., 2010). Therefore, as mentioned previously, the choice of environmental factors to 189 include in the analysis (and their transformation, weighting and numerical resolution), the classification method and choice of number of groups, may influence the final delineation of

191 hydrologic regions (Snelder et al., 2007). Furthermore, some aspects of stream hydrology are 192 poorly explained using environmental surrogates due to the coarse resolution of available data 193 (e.g., geology layers to describe groundwater contributions), which may also limit the utility of 194 environmentally-deduced classifications.

195

\section{Inductive Approach}

\section{Streamflow classification}

198 Streamflow classification involves the direct delineation of patterns in hydrologic character 199 through inductive approaches that use attributes describing different components of the multi200 faceted flow regime. In this approach, classification schemes attempt to provide order to 201 inherently complex flow data by identifying and characterizing similarities among rivers 202 according to a set of diagnostic hydrologic metrics that vary spatially across the landscape (e.g. 203 Mosley, 1981; Jowett and Duncan, 1990; Poff, 1996; Hannah et al., 2000; Harris et al., 2000; 204 Snelder et al., 2009a; Kennard et al., 2010b). Streamflow classification relies on hydrologic 205 metrics that describe the various components of the flow regime, including the seasonal 206 patterning of flows; timing of extreme flows; the frequency, predictability, and duration of 207 floods, droughts, and intermittent flows; daily, seasonal, and annual flow variability; and rates of 208 change (Olden and Poff, 2003; Figure 4). Hydrologic metrics are often selected to account for 209 characteristics of the flow variability that are hypothesized to be important in shaping ecological 210 and physical processes in lotic ecosystems. Many of these metrics have proven to be suitable for 
211 hydrologic classification (Kennard et al., 2010b), and are responsive to hydrologic alteration

212 caused by human activities such as river regulation by dams, urbanization, and projected climate 213 change (Richter et al., 1996; Bunn and Arthington, 2002).

214 Streamflow classification has been conducted for a number of purposes in ecohydrology.

215 Previous efforts have developed classifications at basin, regional, national, continental and global 216 scales, focusing on different components of the flow regime and applying a number of statistical 217 methodologies (Table 2; Appendix A). For example, efforts at global or continental scales have 218 primarily focused on flow seasonality, flood behavior or low flow characteristics of the 219 hydrograph, whereas regional classifications have typically utilized a larger suite of hydrologic 220 metrics. Below we provide a succinct summary of the more common applications of streamflow 221 classification in the literature.

223 Describing patterns in hydrologic variability - Streamflow classifications have commonly been 224 developed to place individual stream sites or reaches into a broader spatial context with the goal 225 of maximizing the transferability of knowledge among rivers of the same hydrologic class.

226 Numerous classifications have been developed to quantify similarities in natural hydrologic 227 characteristics at a variety of scales (Table 2). Poff (1996) identified 10 distinctive flow types 228 seven permanent and three intermittent - in the continental United States based on ecologically 229 relevant hydrological characteristics describing flow variability, predictability and low- and 230 high-flow extremes. Kennard et al. (2010b) presented a continental-scale classification of 231 hydrologic regimes for Australia describing 12 classes of flow-regime types differing in the 232 seasonal pattern of discharge, degree of flow permanence, variation in flood magnitude, and flow 233 predictability and variability (Figure 5a). The geographic distributions of the flow classes varied 234 greatly, as did differences in key hydrologic metrics. At the regional scale, Hughes and James (1989) classified streamflow types in Victoria, Australia, based on 16 hydrologic metrics 236 computed for 138 gauges from daily time series. A low-flow classification scheme produced 237 four distinct classes with a spatially heterogeneous distribution across the state, which was 238 largely determined by topography. In another example, Bejarno et al. (2010) described 15 239 natural flow typologies in the Ebro River Basin, Spain, which were characterized in terms of 240 flow fluctuation through the year as well as timing, flow ratio and duration of the maximum and 241 minimum flows. Groups of streams that are hydrologically distinctive at landscape scales are 
242 expected to discriminate differences in ecological character (Poff et al., 1997). For example, 243 streamflow classes are likely to have similar biological responses to both natural and human244 induced variability in patterns of magnitude, frequency, duration, timing and rate of change in 245 flow conditions. Therefore, systems that show commonalities in their hydrologic characteristics

246 have provided a basis for testing whether hydrology influences the structure and function of 247 biological communities in a similar fashion (e.g. Jowett and Duncan, 1990; Poff and Allan, 1995;

248 Snelder and Lamouroux, 2010).

250 Aiding water resource management - Streamflow classification based on spatial variation in stream hydrology can play a central role in river ecosystem planning (e.g., Snelder et al., 2004) and environmental flow assessments for water management. Holistic methodologies to

253 environmental flow assessments, such as the application of the benchmarking methodology

254 (Brizga et al., 2002), Downstream Response to Imposed Transformations (King et al., 2003), and 255 the Ecological Limits of Hydrologic Alteration (ELOHA: Poff et al., 2010), either implicitly or 256 explicitly involve the hydrologic classification of rivers. Streamflow classification is the first 257 step in the ELOHA framework and serves two important purposes. First, by assigning rivers or 258 river segments to a particular type, relationships between ecological metrics and flow alteration 259 can be developed for an entire river type based on data obtained from a limited set of rivers of 260 that type within the region. Thus classification can help establish the expected ecological 261 condition of river basins by class, which alleviates the burden of developing ecological standards 262 on a river-by-river basis. Second, a streamflow classification facilitates efficient biological 263 monitoring and research design by informing the strategic placement of monitoring sites 264 throughout a region to capture the range of flow conditions (Arthington et al., 2006; Poff et al., 265 2010). Recent efforts have also called for greater focus on how rivers in different classes vary 266 with respect to the degree of human influence (e.g., land use, river regulation), thus providing a 267 benchmark against which the response of biological communities to these factors can be assessed 268 and a better understanding of the extent to which impacts and management options are 269 conditional on river class (Peterson et al., 2009; Poff et al., 2010).

271 Identifying and prioritizing conservation efforts for freshwater ecosystems - Recent interest has 272 focused on the spatial prioritization of freshwater ecosystems for conservation of regional-scale 
273 biodiversity (Abell et al., 2007). Hydrologic classification (inductive or deductive) may be a 274 useful tool for the identification of streams, rivers or entire catchments with representative flow 275 regimes, and therefore, representative biological communities (Nel et al., 2007). Broadly, 276 environmental classes are often used as biodiversity surrogates as different types of

277 environments are assumed to support different combinations of species (Margules et al., 2002).

278 Following the premise that flow is a key driver of aquatic ecosystem structure and function, 279 identifying streams and rivers that exhibit distinct or representative flow regimes using 280 hydrological classification can aid in the selection of those river systems that can contribute to 281 dynamic conservation reserves to support ecosystem resilience and maintenance of biodiversity 282 (e.g. Nel et al., 2007; Snelder et al., 2007).

285 Hydrologic classification should be a process that, ideally, is adequately transparent, readily 286 interpretable, account for uncertainty and for hydrologic variability at multiple temporal and 287 spatial scales, recognize methodological biases and robustness, and provide definable class 288 boundaries, objective group membership, and information on the diagnostic hydrologic 289 characteristics of each class. To maximize the ability to achieve (at least in part) these 290 requirements, we believe that a hydrologic classification system should be based on a defensible 291 scientific framework. Below, we provide a specific protocol to help reach this goal, highlighting 292 all of the aforementioned approaches to hydrologic classification and focusing specifically on 293 streamflow classification.

1) Define the objectives of the hydrologic classification

a) Deductive approaches are selected when the study seeks a general description of perceived hydrologic patterns based on first principles with an emphasis on the ease of understanding. Limited availability and quality of streamflow data may also necessitate deploying a deductive approach.

i) Environmental regionalization. The objective is to quantify environmental similarity using readily-available maps and spatial data, producing a simple classification of 
contiguous or non-contiguous regions that are considered homogeneous with respect to certain environmental characteristics at a particular scale.

ii) Hydrologic regionalization. The objective is to extend insights gained from wellgauged regions to ungauged or sparsely gauged regions or rivers by relating catchment environmental characteristics to hydrologic metrics describing the flow regime within defined groups that are considered to exhibit similar hydrologic characteristics.

iii) Environmental classification. The objective is to classify sites according to similarities in hydrologically-relevant environmental datasets (e.g. describing climate, catchment topography, soils and geology, vegetation and land use) that are assumed to control hydrological processes (e.g. precipitation, storage and release of water by watersheds).

2) Acquire and evaluate the hydrologic data

a) Determine availability of discharge data. Data may be gauged or modeled, recorded at daily, monthly or annual time steps, span short or long time periods, and vary in geographic coverage.

b) Select candidate set of gauges (if using gauged discharge data). If your purpose is to classify "natural" flow regimes (the most common application in the literature), then only include gauges that are minimally affected by human activities (e.g. dams, water extraction, land-use) using best available information (e.g. spatial patterns of land-use, dam location and attributes, expert knowledge and input from water managers).

c) Evaluate quality of discharge data (i.e. missing data, poor measurement recordings as indicated by quality codes) and eliminate gauges with large data gaps and unsatisfactory records.

d) Ensure consistency of discharge measurement units among gauges (e.g. $\mathrm{m}^{3} \cdot \mathrm{sec}^{-1} \mathrm{vs}$. $\left.\mathrm{ML} \cdot \mathrm{day}^{-1}\right)$. 
e) Evaluate temporal period (e.g. 1965-2000) and duration (i.e. 35 years) of available discharge data for each gauge, and decide on criteria for inclusion of gauge data. Important considerations include: minimum vs. fixed record length, completely overlapping vs. partially overlapping period of record, and period of record to include particular environmental events (e.g. years including significant changes in climate). Screening for long-term trends in hydrologic characteristics (e.g. based on annual values of mean, minimum, and/or maximum flows) can help to clarify the extent to which the chosen time period is likely to influence the hydrologic classification. Based on a sensitivity analysis, Kennard et al. (2010a) recommend that at least 15 years of daily discharge data is suitable for use in hydrologic classifications (to maximize precision and minimize bias in the estimation of the hydrologic metrics), provided that gauge records are contained within a discrete temporal window (i.e. preferably $>50 \%$ overlap between records).

f) Evaluate spatial distribution of gauges that meet the above criteria to ensure adequate geographic coverage (e.g. representing climate regions of interest). If the spatial coverage is not sufficient, then evaluate potential for including additional gauges by:

i) Relaxing the acceptance criteria (steps $2 b, c, e$ ), and/or

ii) Estimating missing or poor quality data in the discharge time series (step 2c) by using linear interpolation for short periods, general linear regression for longer periods, or another appropriate technique.

Note that relaxing the acceptance criteria will decrease the comparability of gauges, and estimating missing data will increase the measurement uncertainty of flow data. Both options will compromise bias and precision of classification results, although some hydrologic indices are more sensitive to record length and period overlap than others (see Kennard et al., 2010a).

3) Select hydrologic metrics

a) Select hydrologic metrics according to purpose of the study. Olden and Poff (2003) provide a comprehensive review of the most commonly used hydrologic metrics, but 
importantly, metric selection will influence the outcome of the hydrologic classification. Considerations for metric selection include:

i) General ecological rationale: Select a suite of metrics that characterize the totality of the flow regime.

ii) Specific ecological rationale: Select individual metrics that are known or hypothesized to have ecological importance for the specific target response(s) of interest (e.g. species, community, or ecosystem properties).

iii) Driver rationale: Select a suite of metrics that is sensitive to an environmental or anthropogenic driver of interest (e.g. urbanization, river regulation, climate change).

b) Select hydrologic metrics that are appropriate for the temporal grain of flow data (e.g. metrics describing flow spell duration are more suited to daily or weekly data than monthly or annual data; see also Poff, 1996).

4) Compute hydrologic metrics

c) Select hydrologic metrics depending on available software and the user's experience with computer programming. Software options include dedicated hydrologic software such as the Indicators of Hydrologic Alteration (Richter et al., 1996), Hydrologic Assessment Tool (Henriksen et al., 2006), the River Analysis Package (www.toolkit.net.au/rap), and a number of others.

d) Select hydrologic metrics based on minimizing statistical redundancy among metrics. The results will inform variable selection and dimensionality reduction (e.g. indirect ordination approaches to produce composite variables, such as Principal Component Analysis) if multicollinearity among metrics is a concern (see Olden and Poff, 2003), and may lead to more robust classifications (Snelder et al., 2009b).

e) No hydrologic metrics are chosen. Hydrologic classification will proceed using parameter sets calculated from any number of time series tools available to analyze hydrographs, including autoregressive integrated moving average (ARIMA) models, Fourier analysis, and wavelets (e.g., Smith et al., 1998; Lundquist and Cayan, 2002; Sabo and Post, 2008).
a) Calculate the metric values for each flow record according to decisions made in step 3 . 
b) Screen datasets for outliers and/or gauges potentially affected by anthropogenic activity or unknown factors (i.e. used in conjunction with step 2b). Potential approaches include: i) Examining diagnostic plots and descriptive statistics.

ii) Conducting indirect ordination (e.g. Principal Component Analysis), plotting ordination scores of gauges in multi-dimensional space and looking for outliers that might be suggestive of modified flows, unique natural flows, or errors in discharge measurement, data entry or metric calculation.

iii) Plotting mean daily flow (or similar hydrologic metric) against catchment area, allowing gauges with obviously different discharge (either through extraction or supplementation) to be identified.

c) Eliminate gauges if necessary.

d) Estimate uncertainty in hydrologic metrics caused by different lengths and periods of gauge records (also see step 2e). Although commonly overlooked, a robust classification system should explicitly incorporate (or in the least, examine) uncertainty in the hydrologic metrics that ultimately underlying the classification scheme. Uncertainty values can be used to weight metrics in the classification process and/or metrics with high uncertainty can be eliminated from the analysis. See Kennard et al. (2010a,b) for more details. This step is optional, but recommended.

e) Remove scale-dependence of flow magnitude metrics (if required, depending on objectives of the study) by standardizing values by catchment area, mean daily flow, or a similarly suitable variable.

5) Conduct the hydrologic classification

a) Select hydrologic metrics to include in classification analysis. Choice of metrics might also be dependent on statistical assumptions/requirements (data type, normality, etc.) of classification approach. Selections might include:

i) All flow metrics.

ii) Subset(s) of metrics describing separate components of flow regime (this decision depends on the purpose for classification). 
iii) Subset(s) of metrics that are non-redundant (i.e. low multicollinearity) and highly informative (i.e. explaining dominant gradients of variation that exist in the larger set of metrics). See Olden and Poff (2003) for more details.

b) Decide whether metric transformations and/or standardizations are required (again, this depends on statistical assumptions/requirements of classification approach).

c) Conduct hydrologic classification analysis using a statistical approach that corresponds with the objective of classification and capability of the researcher. Ordination analyses may also be conducted to complement hydrologic classification, explore the extent of hydrologic variability and examine for natural clusters of stream gauges and/or outliers. See Methodologies section below.

d) Delineate and decide on the number of hydrologic classes (i.e. clusters) based on objective (statistical) criteria, ecological rationale and/or considering a trade-off between resolution of hydrological variability and complexity (number of classes). Depending on

6) Interpret and/or spatially-model the hydrologic classification the purpose of the classification, each approach may be legitimate for deciding on the number of classes. Assign class membership. See Methodologies section below.

e) Examine classification results for outliers and eliminate gauges if necessary; repeat steps

a) Assess the predictive performance of the hydrologic classifier using an independent dataset containing gauges not included in the classification (e.g., cross-validation) according to an appropriate statistical approach (e.g. coefficient of agreement such as Cohen's Kappa statistic). When model performance is poor and the uncertainty of classifications are high, this may indicate an inadequate understanding of watershed behavior or an inability to know or estimate the salient hydrologic characteristics. The result is a classification system with low power and utility.

b) Diagnose the distinguishing characteristics of the hydrologic classes using numerical, statistical, graphical, and descriptive approaches.

c) Examine geographic distribution of gauge class membership.

d) Depending on the study purpose, model class membership of gauges based on upstream physiographic characteristics (e.g. drainage area, stream slope, soil type) and climatic 
variables (e.g. precipitation, temperature, evapotranspiration) of the watershed using an appropriate statistical approach (e.g. logistic regression, discriminant function analysis, classification tree). Assuming adequate model performance (see Snelder et al., 2007 for discussion) the user can predict hydrologic class membership by applying model at the river segment scale. See Methodologies section below.

\section{METHODOLOGIES FOR STREAMFLOW CLASSIFICATION}

The objective of streamflow classification is to ascribe objects (i.e., streams, rivers, catchments) to empirically-based groupings or classes, so as to maximize the similarity between the members of each group and minimize the similarity between groups. By virtue of the many ways that the various components of the flow regime can be characterized (see Olden and Poff, 2003), the statistical techniques for organizing rivers into hydrologic classes are numerous and vary in their output. Below we discuss some of the more common approaches to streamflow classification, and examine some important considerations with respect to delineating and deciding on the number of hydrologic classes (i.e. clusters) and assigning class membership.

\section{Ordination approaches to exploring hydrologic variability}

Multivariate ordination is typically used to explore continuous patterns in hydrologic variability among sites (e.g. Lins, 1997; Clausen and Biggs, 2000) and complement clustering-based classifications that assign sites to classes (see below). Commonly employed approaches include Principal Component Analysis (PCA) or non-metric multidimensional scaling. Ordination approaches do not produce a classification; rather the relative hydrological similarity/dissimilarity of different objects (i.e. gauging locations) is displayed in multivariate space of reduced dimensionality, thus allowing the investigator to visually determine whether objects group together in well-defined sets or form contrastingly poorly-defined and overlapping groups. One property of most classification algorithms is that they force a grouped structure on what may otherwise be a continuously varying distribution and ordination is a useful tool to assess whether any such grouping is warranted. Other approaches for exploring hydrologic variation, although rarely used, include graphical representation of multi-dimensional data using Andrews curves (Andrews, 1972) and a range of pictorial techniques that involve "entertaining 
483

transmogrifications” (Nathan and McMahon, 1990) of cartoon faces, trees, castles, and dragonflies (see Chernoff, 1973).

\section{Clustering approaches to developing a streamflow classification}

Hierarchical clustering has been most commonly applied for streamflow classification. These algorithms produce a classification of objects (typically presented as a dendrogram), starting with each stream site (gauge) in a separate cluster and combining clusters until only one is left (agglomeration approach) or by splitting larger clusters into smaller ones (divisive approach). As pointed out by Nathan and McMahon (1990), a major consideration encountered when using cluster analysis for streamflow classification is the plethora of different computational algorithms and distance/dissimilarity measures available. Unfortunately, different clustering algorithms applied to the same set of data can produce classifications that are substantially different because each approach implicitly imposes structure on the data. Therefore, the choice of algorithm used in hydrologic classification is paramount.

Seven algorithms for agglomerative hierarchical clustering have been commonly applied in the past (Table 2), including (i) single linkage; (ii) complete linkage; (iii) average linkage (either weighted or unweighted); (iv) centroid linkage; (v) median linkage; (vi) density linkage; and (vii) Ward's minimum-variance algorithm. Each algorithm has both strengths and weaknesses (see Gordon (1987) for a good overview from a statistical perspective), but perhaps the most relevant feature for streamflow classification is the tendency of algorithms to 'distort' space, thus affecting the clustering results (see Everitt et al., 2001). The 'chaining' effect, in which dissimilar objects are sequentially drawn into the same cluster, is an example of space contraction and is commonly produced by the single linkage algorithm. Such approaches tend to identify highly distinctive groups and may see their greatest use in conservation when practitioners are seeking to reveal unique and rare hydrologic environments. By contrast, space dilation refers to the process of favoring the fusion of clusters together, and is typical of the complete linkage algorithm. These approaches tend to produce groups of equal size and may be best applied in hydrologic regionalization to ensure adequate sample sizes to establish statistical relationships. Lastly, space-conserving methods, such as average linkage, merge clusters in a manner that best balances space contraction and dilation, and therefore, the resulting dendrogram best represents the original data structure. The choice of clustering algorithm will depend on the 
514 objective of the classification exercise, but for most applications we would recommend space 515 conserving approaches, such as average linkage or Ward’s algorithm. The latter is quite

516 beneficial because it maximizes the cophenetic correlation between the original and dendrogram

517 distances and eliminates group size dependencies on the clustering results. Selection of an

518 appropriate (dis)similarity index is also important, but for continuous variables such as the 519 majority of commonly used hydrologic metrics, standardized Euclidean distance remains the 520 most popular. However, other indices have favorable properties (i.e., minimizing the influence 521 of large distances) and may be preferred (see Legendre and Legendre, 1998).

522 Partitional clustering techniques have also been applied for streamflow classification. This 523 family of methods seeks to identify clusters of equal distinction, and thus is not represented in a 524 hierarchy. Examples include K-means, K-median, K-modes and K-medoids algorithms, where 525 K-means is by far the most commonly used. This algorithm groups cases according to a distance 526 measure (typically Euclidian distance) from initial, randomly chosen cluster centers of a 527 predetermined number, and then it iteratively redefines cluster centers as the means of the cases 528 in the latest cluster, until cases no longer change in membership (Everitt et al., 2001). The 529 method is efficient for large datasets, and results are often sufficient, although subjectivity of the 530 initial number of clusters and the location of their centroids in n-dimensional space must be 531 considered.

532 While the hierarchical clustering procedures are not influenced by initialization and local 533 minima, the partitional clustering procedures are influenced by initial guesses (number of 534 clusters, cluster centers, etc.). The partitional clustering procedures are dynamic in the sense that 535 objects can move from one cluster to another to minimize the objective function. By contrast, 536 the objects committed to a cluster in the early stages cannot move to another in hierarchical 537 clustering procedures. The relative merits of the hierarchical and partitional clustering methods 538 resulted in the development of hybrid-clustering methods that are a blend of these methods. For 539 example, Rao and Srinivas (2006a) used a partitional clustering procedure to identify groups of 540 similar catchments by refining the clusters derived from agglomerative hierarchical clustering 541 using the K-means algorithm. Similarly, Kahya et al. (2007) considered results of an average 542 linkage algorithm to help identify an optimal number of hydrologic classes of Turkey streams for 543 subsequent flat classification using K-means. 
546 Determining the number of distinct classes is a problem inherent to most if not all conventional 547 clustering techniques. For partitional algorithms, the number of clusters must be predetermined 548 before the patterns of input data have been analyzed. For hierarchical algorithms, selection of 549 the degree of cluster distinction between tiers is subjective. Several approaches for optimizing 550 the number of clusters have been discussed in the literature and are relevant for hydrologic 551 classification (Milligan and Cooper, 1985). In hierarchical clustering, partitions are achieved by 552 selecting one of the solutions in the nested sequence of clusters that comprise the hierarchy. This 553 is equivalent to cutting down the dendrogram at a particular height in which the appearance of 554 distinct classes is present. Although this procedure is commonly used, it does carry with it the 555 high possibility of influence from a priori expectations. More formal methods for determining 556 the number of clusters are reviewed by Milligan and Cooper (1985). Among the many they reviewed, the authors identified "best” approaches - including those based on the ratio of between-cluster to within-cluster sums of squares.

Expert opinion can also guide the selection process. Snelder and colleagues (Snelder and Hughey, 2005; Snelder et al., 2007) suggest that the definition of most classifications cannot be entirely objective as it rare that all parts of the hydrological space are represented, thus no optimal number of classes exists. Moreover, where classifications serve some managerial utility: then trade-offs between resolution of hydrological variability and complexity (number of classes', may be needed and are then guided by other than mathematical elegance (i.e. simple pragmatism). To date, we fear that the lack of application and consensus about which rule to apply have resulted in informal and subjective criteria in the selection of hydrologic classes. We urge that investigators become more explicit on the criteria that they apply.

Assigning class membership: hard vs. soft classification

570 Clustering algorithms can lead to either hard or soft (i.e. fuzzy) classifications. A hard clustering 571 method is based on the assumption that stream sites can be divided into non-overlapping clusters 572 (i.e. hydrologic class) with well-defined boundaries between them, and each site is assigned to a 573 single cluster with a high degree of certainty. In other words, a stream is classified as belonging 574 to a cluster on the basis of distance (or dissimilarity) between itself and the cluster centroid in the 575 multi-dimensional space of attributes depicting the flow variation. 
It is reasonable to suppose, however, that most streams partially resemble several other streams and therefore a hard assignment to one class (cluster) may not be justified. Consequently, identifying classes with vague boundaries between them is preferable, compared to crisp classification with well-defined boundaries as in the case of hard clustering. The fuzzy set theory that straddles ordination, classification and clustering analysis (Roberts, 1986) is a natural way to represent such a situation. Fuzzy partitional clustering allows a stream site to belong to all the regions simultaneously with a certain degree of membership. The distribution of membership of a stream among the fuzzy clusters specifies the strength with which the stream belongs to each class and is useful to identify ambiguous sites. A threshold to maximum membership values can be applied to derive crisp, vector-based representations from raster, fuzzy classifications. Rao and Srinivas (2006b) argue that given the inadequacies of conventional stream classification methods, fuzzy representations of hydrologic variability present an appealing alternative.

Another fuzzy partitional method available is Bayesian mixture modeling (Gelman et al., 2004). In this approach, the observed distribution of data is modeled as a mixture of a finite number of component distributions in order to determine the number of distributions, their parameters, and object memberships (Webb et al., 2007). The approach is fully probabilistic and uncertainty can be explicitly reported in terms of data specification, class specification and the final classification chosen. Multiple plausible classifications are produced, which are then ranked on their estimated marginal likelihoods to select the most parsimonious classification that is guaranteed to have the highest posterior probability; the probability of the model being correct given the data (Gelman et al., 2004; Webb et al., 2007). To date, Kennard et al. (2010b) represents the only application of fuzzy clustering for streamflow classification; here, the authors used 120 hydrologic metrics to quantify the likelihood of 830 stream gauges to belong to 12

602 Predicting landscape patterns of streamflow classes

603 Knowledge of probable class membership within a streamflow classification allows hydrologic 604 behavior to be predicted for a target site or stream. For example, hydrologists frequently use 605 regression models developed for specific clusters within a classification to predict hydrology of a 606 novel stream (i.e. regionalization) after determining to which class it should belong (Lin and 
607 Wang, 2006). The key issue, therefore, is how class membership for novel locations is

608 determined given that geographic proximity alone is not always a sufficient rationale (Ouarda et

609 al., 2001; Poff et al., 2006). Several methods are available to predict class membership using

610 upstream physiographic characteristics (e.g., drainage area, stream slope, soil type) and climatic

611 variables (e.g., precipitation, temperature, evapotranspiration) of the watershed based on an

612 appropriate statistical model. Linear discriminant analysis (LDA) is one such method in which

613 linear combinations of potential predictor variables are used to allocate group membership. LDA

614 has a number of requirements and assumptions that are not always met when applied to

615 environmental data (e.g., multivariate normality of predictor variables), however LDA has been

616 appropriately used in a variety of ecohydrological analyses (e.g. Pusey and Arthington, 1996;

617 Detenbeck et al., 2005; Jowett and Duncan, 1990; Sanborn and Bledsoe, 2006). Alternative non-

618 parametric and/or machine learning methods are available (see Olden et al., 2008; Kampichler et

619 al., 2010) and have been used to allocate cluster group membership in hydrologic analyses (e.g.,

620 Reidy Liermann et al., 2011). For example, classification trees were used by Kennard et al.

621 (2010b) to identify a subset of climatic and landscape variables that were able to predict flow

622 regime class membership with a relatively high success rate of $62.1 \%$ (Figure $5 b$ ). In another

623 example, Snelder et al. (2009a) used boosted regression trees and watershed variables describing

624 climate, topography, and geology, to predict natural flow classes for stream segments in France

625 with $87 \%$ accuracy.

626 The examples above all involve a two-step process; the classification is developed and then

627 potential predictor variables are assessed and combined to predict class membership. Lin and

628 Wang (2006) suggest that this is an inefficient process and describe a machine learning approach

629 based on self-organizing maps (SOM: Kohonen 2000) in which cluster analysis and

630 discrimination analysis is performed in one analysis. Their SOM-based cluster and

631 discrimination analysis produces three maps in a single step for use in classification. The feature

632 density and discrimination maps can be used to assign unknown catchments to classes at one

633 time, eliminating the step of post-clustering discriminant analysis for each unknown catchment.

634 As well, the ability to define the number of clusters at multiple resolutions from the feature and

635 density maps is argued as a key advantage of the method.

636 The capacity to predict streamflow class membership provides, in addition to increased

637 knowledge of what factors drive hydrologic variation, a means by which a classification may be 
638 extrapolated to all locations within the spatial domain of the input variables. Thus, a map of flow 639 regime variation can be constructed. For example, Snelder et al. (2009a) developed a natural

640 flow regime classification of continental France using non-hierarchical K-means cluster analysis.

641 Boosted regression tree models were used to predict the likelihood of gauging stations belonging

642 to identified clusters based on watershed characteristics and these models were used to

643 extrapolate the classification to all $\sim 115,000$ segments of a national river network. Snelder and

644 Hughey (2005) and Arthington et al. (2006) argue that such a spatial framework has practical

645 use. A spatially explicit classification aids in exploring the influence of streamflow on biological

646 communities and ecological processes, prioritizing conservation efforts for freshwater

647 ecosystems and guiding river management strategies.

\section{CONCLUSION}

Hydrologic classification is increasingly being used to guide and aid the management of aquatic resources. No single classification will suit all purposes, as classification is a tool not an end in itself. Rather, different approaches and many different means of classifying locations, stream reaches or catchments are available and the choice of which approach and which classification

654 method is employed depends on the availability of data and the desired purpose of the 655 classification. In the case where high quality hydrologic information is sparse or lacking for 656 some areas, the deductive approach is appropriate. This approach varies from simple 657 environmental or hydrologic regionalizations in which region membership is qualitatively 658 assigned, to regionalizations in which membership is quantitatively assigned based on 659 similarities across a number of environmental (climatic, topographic etc) variables that are 660 assumed to have direct influence on streamflow. The inductive approach, in contrast, is based on 661 quantitative classification, achieved by a variety of methods, in which classification group 662 membership is based on similarity in various metrics describing aspects of the flow regime for 663 individual locations. Whatever the approach used, the steps taken in the formation of a 664 classification need to be explicitly described including criteria used for data selection, data 665 treatment and assessment, metric selection and rationale, and classification method including 666 explicit rationale for derivation of final group number. These steps are integral to the framework 667 described here. 
669 We thank Chris Konrad, Ton Snelder and an anonymous reviewer for constructive comments 670 that greatly improved the final paper. Funding was gratefully provided by the USGS National 671 Gap Analysis Program (JDO), the U.S. Environmental Protection Agency Science To Achieve 672 Results (STAR) Program (Grant No. 833834) (JDO), and the Tropical Rivers and Coastal 673 Knowledge (TRaCK) Research Hub through the Australian Rivers Institute, Griffith University

674 (MJK, BJP and JDO). TRaCK receives major funding for its research through the Australian 675 Government's Commonwealth Environment Research Facilities initiative; the Australian 676 Government's Raising National Water Standards Program; Land and Water Australia; the 677 Fisheries Research and Development Corporation; the National Environmental Research 678 Program and the Queensland Government’s Smart State Innovation Fund.

\section{REFERENCES}

681

Abell R, Allan JD, Lehner B. 2007. Unlocking the potential of protected areas for freshwaters. Biological Conservation 134: 48-63.

Acreman MC, Sinclair CD. 1986. Classification of drainage basins according to their physical characteristics; an application for flood frequency analysis in Scotland. Journal of Hydrology 84: 365-380.

Andrews DF. 1972. Plots of high dimensional data. Biometrics 28: 125136.

Arthington AH, Bunn SE, Poff NL, Naiman RJ. 2006. The challenge of providing environmental flow rules to sustain river ecosystems. Ecological Applications 16: 1311-1318.

Assani AA, Tardif S. 2005. Classification and characterization of natural flow regimes in Quebec (Canada). Factors of spatial variability - an eco-geographical approach. Revue Des Sciences De L’Eua 18: 247-266.

Baeza Sanz D, Garcia del Jalon D. 2005. Characterisation of streamflow regimes in central Spain, based on relevant hydrobiological parameters. Journal of Hydrology 310: 266-279. Bailey RG. 1996. Ecosystem Geography. Springer-Verlag, New York.

Bejarano MD, Marchamalo M, de Jalón DG, Tánago MG. 2010. Flow regime patterns and their controlling factors in the Ebro basin (Spain). Journal of Hydrology 385: 323-335. 
Bower D, Hannah DM, McGregor GR. 2004. Techniques for assessing the climatic sensitivity of river flow regimes. Hydrological Processes 18: 2515-2543.

Brizga SO, Arthington AH, Pusey BJ, Kennard MJ, Mackay SJ, Werren GL, Craigie NM Choy

SJ. 2002. Benchmarking, a 'top-down' methodology for assessing environmental flows in Australian rivers. In Proceedings of International Conference on Environmental Flows for Rivers, Cape Town, SA.

Bryce SA, Clarke SE 1996. Landscape-level ecological regions: linking state-level ecoregion frameworks with stream habitat classifications. Environmental Management 20: 297-311.

Bunn SE, Arthington AH. 2002. Basic principles and ecological consequences of altered flow regimes for aquatic biodiversity. Environmental Management 30: 492-507.

Burn DH, Arnell NW. 1993. Synchronicity in global flood responses. Journal of Hydrology 144: 381-404.

Buttle J. 2006. Mapping first-order controls on streamflow from drainage basins: the T3 template. Hydrologic Processes 20: 3415-3422.

Carlisle DM, Falcone J, Wolock DM, Meador MR, Norris RH. 2010. Predicting the natural flow regime: models for assessing hydrological alteration in streams. River Research and Application 26: 118-136.

Chang FJ, Tsai MJ, Tsai WP, Herricks EE. 2008. Assessing the ecological hydrology of natural flow conditions in Taiwan. Journal of Hydrology 354: 75-89.

Chernoff H. 1973. Using faces to represent points in k-dimensional space graphically. Journal of the American Statistics Association 68: 361368.

Chiang S-M, Tsay T-K, Nix SJ. 2002. Hydrologic regionalization of watersheds I: Methodology development. Journal of Water Resource Planning and Management 128: 3-11.

Clausen B, Biggs BJF. 2000. Flow variables for ecological studies in temperate streams: groupings based on covariance. Journal of Hydrology 237: 184-197.

Detenbeck NE, Batterman SL, Brady VL, Brazner JC, Snarski VM, Taylor DL, Thompson J, Arthur JW. 2000. A test of watershed classification systems for ecological risk assessment. Environmental Toxicology and Chemistry 19: 1174-1181.

Detenbeck NE, Brady VJ, Taylor DL, Snarski VM, Batterman SL. 2005. Relationship of stream flow regime in the western Lake Superior basin to watershed type characteristics. Journal of Hydrology 309: 258-276. 
Dettinger MD, Diaz HF. 2000. Global characteristics of stream flow seasonality and variability. Journal of Hydrometeorology 1: 289-310.

Everitt, BS, Landau S, Leese M. 2001. Cluster Analysis (fourth ed), Arnold, London (2001)

Fielding AH, Bell JF. 1997. A review of methods for the assessment of prediction errors in conservation presence/absence models. Environmental Conservation 24: 38-49.

Finlayson BL, McMahon TA. 1988. Australia vs. the World: A comparative analysis of streamflow characteristics. Pp 17-40 In: Werner RF (ed.), Fluvial Geomorphology of Australia, Academic Press, Sydney.

Gelman A, Carlin JB, Stern HS, Rubin DB. 2004. Bayesian Data Analysis. 2nd edition. Chapman and Hall/CRC Press, Boca Raton, Florida.

GeoSciences Australia. 2006. GEODATA TOPO 250K Series 3. Shape Files Format. Commonwealth of Australia (GeoSciences Australia), Canberra, ACT, Australia.

Gordon A. 1987. A review of hierarchical classification. Journal of the Royal Statistical Society.

\section{Gottschalk L, Lundager J, Lundquist D, Solantie R, Tollan A. 1979. Hydrologic regions in the} Nordic countries. Nordic Hydrology 10: 273-286.

Gottschalk L. 1985. Hydrological regionalization of Sweden. Hydrological Science 30: 65-83. Haines AT, Findlayson BL, McMahon TA. 1988. A global classification of river regimes. Applied Geography 8: 255-272.

Hannah DM, Smith BPG, Gurnell AM, McGregor GR. 2000. An approach to hydrograph classification. Hydrological Processes 14: 317-338.

Hannah DM, Kansakar SR, Gerrard AJ, Rees G. 2005. Flow regimes of Himalayan rivers of Nepal: nature and spatial patterns. Journal of Hydrology 308: 18-32.

Harris NM, Gurnell AM, Hannah DM, Petts GE. 2000. Classification of river regimes: a context for hydroecology. Hydrological Processes 14: 2831-2848.

Henriksen JA, Heasley J, Kennen JG, Niewsand S. 2006. Users' manual for the hydroecological integrity assessment process software (including the New Jersey Assessment Tools): U.S. Geological Survey, Biological Resources Discipline, Open File Report 2006-1093, 71 p.

Hughes DA, Hannart P. 2003. A desktop model used to provide an initial estimate of the ecological instream flow requirements of rivers in South Africa. Journal of Hydrology 270: 167-181. 
Hughes JMR. 1987. Hydrological characteristics and classification of Tasmanian rivers. Australian Geographical Studies 25: 61-82.

Hughes JMR, James B. 1989. A hydrological regionalization of streams in Victoria, Australia, with implications for stream ecology. Australian Journal of Marine and Freshwater Resources 40: 303-326.

Jowett IG, Duncan MJ. 1990. Flow variability in New Zealand rivers and its relationship to instream habitat and biota. New Zealand Journal of Marine and Freshwater Research 24: 305317.

Kachroo RK, Mkhandi SH, Parida BP. 2000. Flood frequency analysis of southern Africa: I. Delineation of homogeneous regions. Hydrological Science 45: 437-447.

Kahya E, Demirel MC, Piechota TC. 2007. Spatial grouping of annual streamflow patterns in Turkey. Paper presented at Hydrology Days, Colorado State Univ. (Available at: http://hydrologydays.colostate.edu/Papers_2007/Demirel_Kahya_paper.pdf).

Kampichler C, Wieland R, Calmé S, Weissenberger H, Arriaga-Weiss S. 2010. Classification in conservation biology: A comparison of five machine-learning methods. Ecological Informatics 5: 441-450.

Kennard MJ, Olden JD, Arthington AH, Pusey BJ, Poff NL. 2007. Multi-scale effects of flow regime, habitat, and their interaction on fish assemblage structure in eastern Australia. Canadian Journal of Fisheries and Aquatic Sciences 64: 1346-1359.

Kennard MJ, Pusey BJ, Mackay SJ, Olden JD, Marsh N. 2010a. Quantifying uncertainty in estimation of hydrologic metrics for ecohydrological studies. River Research and Applications 26: 137-156.

Kennard MJ, Pusey BJ, Olden JD, Mackay SJ, Stein JL, Marsh N. 2010b. Classification of natural flow regimes in Australia to support environmental flow management. Freshwater Biology 55: 171-193.

King JM, Brown CA, Sabet H. 2003. A scenario-based holistic approach to environmental flow assessments for rivers. River Research and Applications 19: 619-640.

Kohonen T. 2000. Self organizing maps. $3^{\text {rd }}$ edition. Berlin: Springer-Verlag. 521 pp.

Kondolf GM. 1995. Cases studies and reviews. Geomorphological stream channel classification in aquatic habitat restoration: uses and limitations. Aquatic Conservation: Marine and Freshwater Ecosystems 5: 127-141. 
Kondolf GM, Montgomery DR, Piégay H, Schmitt L. 2003. Geomorphic classification of rivers and streams. Pp 169-202. In GM Kondolf and H Piégay, (ed.). Tools in Fluvial Geomorphology. Wiley, New York.

Krasovskaia I. 1997. Entropy-based grouping of river flow regimes. Journal of Hydrology 202: 173-191.

Legendre P, Legendre L. 1998. Numerical Ecology, 2nd edition. Elsevier Scientific, Amsterdam, 796 The Netherlands. 870 pp.

Lin G-F, Wang C-M. 2006. Performing cluster analysis and discrimination analysis of hydrological factors in one step. Advances Water Research 29: 1573-1585.

Lins HF. 1997. Regional streamflow regimes and hydroclimatology of the United States. Water Resources Research 33: 1655-1667.

Loveland TR, Merchant JM. 2004. Ecoregions and ecoregionalization: geographical and ecological perspectives. Environmental Management 34: 1-13.

Lundquist JD, Cayan DR. 2002. Seasonal and spatial patterns in diurnal cycles in streamflow in the western United States. Journal of Hydrometeorology 3: 591-603.

Mackey BG, Berry SL, Brown T. 2007. Reconciling approaches to biogeographical regionalization: a systematic and generic framework examined with a case study of the Australian continent. Journal of Biogeography 35: 213-229.

Margules CR, Pressey RL, Williams PH. 2002. Representing biodiversity: data and procedures for identifying priority areas for conservation. Journal of Biosciences 27: 309-326.

McMahon TA, Vogel RM, Peel MC, Pegram GGS. 2007a. Global streamflows - Part 1: Characteristics of annual streamflows. Journal of Hydrology 347: 243-259.

McMahon TA, Peel MC, Vogel RM, Pegram GGS. 2007b. Global streamflows - Part 3: Country and climate zone characteristics. Journal of Hydrology 347: 272-291.

McManamay RA, Orth DJ, Dolloff CA, Frimpong EA. 2011. Regional frameworks applied to hydrology: Can landscape-based frameworks capture the hydrologic variability? River Research and Applications, in press. DOI: 10.1002/rra.1535.

Meigh JR, Farquharson FAK, Sutcliffe JV. 1997. A worldwide comparison of regional flood estimation methods and climate. Hydrology Science 42: 225-244.

Merz B, Bloeschl G. 2004. Regionalization of catchment model parameters. Journal of Hydrology 287: 95-123. 
821 Milligan GW, Cooper MC. 1985. An examination of procedures for determining the number of 822 clusters. Psychometrika 50: 159-179.

823 Mkhandi SH, Kachroo RK. 1996. Regional flood frequency analysis for southern Africa.

824 Xiièmes Journées Hydrologiques De L’orstom. Montpellier, 10-11th October 1996.

825 Monk WA, Peters DL, Curry RA, Baird DJ. 2011. Quantifying trends in indicator

826 hydroecological variables for regime-based groups of Canadian river. Hydrological

827 Processes, in press. DOI: 10.1002/hyp.8137.

828 Monk WA, Wood PJ, Hannah DM, Wilson DA, Extence CA, Chadd RP. 2006. Flow variability

829 and macroinvertebrate community response within riverine systems. River Research and

$830 \quad$ Applications 22: 595-615.

831 Mosley MP. 1981. Delimitation of New Zealand hydrologic regions. Journal of Hydrology 49:

$832 \quad$ 179-192.

833 Nathan RJ, McMahon TA. 1990. Identification of homogeneous regions for the purposes of 834 regionalization. Journal of Hydrology 121: 217-238.

835 Nel JL, Roux, DJ, Maree G, Kleynhans CJ, Moolman J, Reyers B, Rouget M, Cowling RM.

836 2007. Rivers in peril inside and outside protected areas: a systematic approach to

837 conservation assessment of river ecosystems. Diversity and Distributions 13: 341-352.

838 O’Keefe JH, Uys MC. 2000. The role of classification the conservation of rivers. Pages 445-458

839 in Boon PJ, Davies BR. and Petts GE. (eds), Global perspectives on river conservation:

$840 \quad$ Science policy and practice. John Wiley \& Sons, Chichester.

841 Olden JD, Poff NL. 2003. Redundancy and the choice of hydrologic indices for characterizing

$842 \quad$ streamflow regimes. River Research and Applications 19: 101-121.

843 Olden JD, Lawler JJ, Poff, NL. 2008. Machine learning methods without tears: a primer for 844 ecologists. The Quarterly Review in Biology 83: 171-193.

845 Omernik JM. 2004. Perspectives on the nature and definition of ecological regions.

846 Environmental Management 34: S1-S13.

847 Ouarda TBMJ, Girard C, Cavadias GS, Bobee B. 2001. Regional flood frequency estimation

848 with canonical correlation analysis. Journal of Hydrology 254: 157-173.

849 Pardé M. 1955. Fleuves et rivieres. Collection Armand Colin, Paris, 224 pp.

850 Pegg MA, Pierce CL. 2002. Classification of reaches in the Missouri and lower Yellowstone 851 rivers based on flow characteristics. River Research and Applications 18: 31-42. 
852 Peterson JT, Jackson CR, Shea CP, Li G. 2009. Development and evaluation of a stream channel 853 classification for estimating fish responses to changing streamflow. Transactions of the American Fisheries Society 138: 1123-1137.

Poff NL. 1996. A hydrogeography of unregulated streams in the United States and an examination of scale-dependence in some hydrological descriptors. Freshwater Biology 36: 71-91.

Poff NL, Allan D, Bain MB, Karr JR, Prestegaard KL, Richter BD, Sparks RE, Stromberg JC. 1997. The natural flow regime: a paradigm for river conservation and restoration. Bioscience 47: 769-784.

Poff NL, Allan JD. 1995. Functional organization of stream fish assemblages in relation to hydrological variability. Ecology 76: 606-627.

Poff NL, Olden JD, Pepin DM, Bledsoe BP. 2006. Placing global stream flow variability in geographic and geomorphic contexts. River Research and Applications 22:149-166.

Poff NL, Richter BD, Arthington AH, Bunn SE, Naiman RJ, Kendy E, Acreman M, Apse C, Bledsoe BP, Freeman MC, Henriksen J, Jacobson RB, Kennen JG, Merritt DM, O’Keeffe JH, Olden JD, Rogers K, Tharme RE, Warner A. 2010. The ecological limits of hydrologic alteration (ELOHA): a new framework for developing regional environmental flow standards. Freshwater Biology 55: 147-170.

Puckridge JT, Sheldon F, Walker KF, Boulton AJ. 1998. Flow variability and the ecology of large rivers. Marine and Freshwater Research 49: 55-72.

Pusey BJ, Arthington AH. 1996. Streamflow variability within the Burdekin River. Proceedings of the 23rd Hydrology and Water Resources Symposium. Pp. 213-220. Australian Institute of Engineers, Barton.

Rao AR, Srinivas VV. 2006a. Regionalization of watersheds by hybrid-cluster analysis. Journal of Hydrology 318: 37-56.

Rao AR, Srinivas VV. 2006b. Regionalization of watersheds by fuzzy cluster analysis. Journal of Hydrology 318: 57-79.

Reidy Liermann CA, Olden JD, Beechie TJ, Kennard MJ, Skidmore PB, Konrad CP, Imaki H. 2011. Hydrogeomorphic classification of Washington State rivers to support emerging environmental flow management strategies. River Research and Applications, in press. DOI: 10.1002/rra.1541 
883 Richter BD, Baumgartner JV, Powell J, Braun DP. 1996. A method for assessing hydrologic $884 \quad$ alteration within ecosystems. Conservation Biology 10: 1163-1174.

885 Roberts DW. 1986. Ordination on the basis of fuzzy set theory. Vegetatio 66: 123-131.

886 Sabo JL, Post DM. 2008. Quantifying periodic, stochastic, and catastrophic environmental 887 variation. Ecological Monographs 78: 19-40.

888 Sanborn SC, Bledsoe, BP. 2006. Predicting streamflow regime metrics for ungauged streams in 889 Colorado, Washington, and Oregon. Journal of Hydrology 325: 241-261.

890 Santhi C, Allen PM, Muttiah RS, Arnold JG, Tuppad, P. 2008. Regional estimation of base flow 891 for the conterminous United States by hydrologic landscape regions. Journal of Hydrology 892 351: 139-153.

893 Sawicz K, Wagener T, Sivapalan M, Troch PA, Carrillo G. 2011. Catchment classification: 894 empirical analysis of hydrologic similarity based on catchment function in the eastern USA. 895 Hydrology and Earth System Sciences Discussions 8: 4495-4534.

896 Schmitt L, Maire G, Nobelis P, Humbert J. 2007. Quantitative morphodynamic typology of 897 rivers: a methodological study based on the French Upper Rhine basin. Earth Surface $898 \quad$ Processes and Landforms 32: 1726-1746.

899 Smith LC, Turcotte DL, Isacks BL. 1998. Stream flow characterization and feature detection 900 using a discrete wavelet transform. Hydrological Processes 12: 233-249.

901 Snelder TH, Biggs BJF. 2002. Multi-scale river environment classification for water resources 902 management. Journal of the American Water Resources Association 38: 1225-1240.

903 Snelder TH, Lamouroux N. 2010. Co-variation of fish assemblages, flow regimes and other 904 habitat factors in French rivers. Freshwater Biology 55: 881-892.

905 Snelder TH, Hughey KFD. 2005. On the use of an ecologic classification to improve water 906 resource planning in New Zealand. Environmental Management 36: 741-756.

907 Snelder TH, Weatherhead M, Biggs BJF. 2004. Nutrient concentration criteria and

908 characterization of patterns in trophic state for rivers in heterogeneous landscape. Journal of 909 the American Water Resources Association 40: 1-13.

910 Snelder TH, Biggs BJF, Woods RA. 2005. Improved eco-hydrological classification of rivers.

911 River Research and Applications 21: 609-628.

912 Snelder TH, Dey KL, Leathwick JR. 2007. A procedure for making optimal selection of input 913 variables for multivariate environmental classifications. Conservation Biology 21: 365-375. 
914 Snelder TH, Lamouroux N, Leathwick JR, Pella H, Sauquet E, Shankar U. 2009a. Predictive

915 mapping of the natural flow regimes of France. Journal of Hydrology 373: 56-67.

916 Snelder TH, Lehmann A, Lamouroux N, Leathwick JR, Allenbach K. 2009b. Strong influence of

917 variable treatment on the performance of numerically defined ecological regions.

918 Environmental Management 44: 658-670.

919 Snelder TH, Booker D, Lamouroux N. 2011. A method to assess and define environmental flow

920 rules for large jurisdictional regions. Journal of the American Water Resources Association,

921 in press. DOI: 10.1111/j.1752-1688.2011.00556.X

922 Stein JL, Hutchinson MF, Pusey BJ, Kennard MJ. 2009. Ecohydrological classification based on

923 landscape and climate data. Appendix 8. In: Pusey BJ, Kennard MJ, Stein JL, Olden JD,

924 Mackay SJ, Hutchinson MF, Sheldon F. (eds), Ecohydrological Regionalisation of Australia:

925 A Tool for Management and Science. Innovations Project GRU36, Final Report to Land and

926 Water Australia. Available at http://lwa.gov.au/products/pn22591.

927 Tasker GD. 1982. Comparing methods of hydrologic regionalization. Water Resources Bulletin

928 18: 965-970.

929 Vogel RM, Wilson I, Daly C. 1999. Regional regression models of annual streamflow for the

$930 \quad$ United States. Journal of Irrigation and Drainage Engineering 125: 148-157.

931 Wagener T, Sivapalan M, Troch P, Woods R. 2007. Catchment classification and hydrologic

932 similarity. Geography Compass 1: 1-31.

933 Ward D, Stein J, Carew R, Kennard M. 2010. Hydrosystem delineation, environmental

934 attribution and classification. Chapter 4. In Kennard MJ. (ed), Identifying high conservation

935 value aquatic ecosystems in northern Australia. Interim Report for the Department of

936 Environment, Water, Heritage and the Arts and the National Water Commission. Tropical

937 Rivers and Coastal Knowledge (TRaCK) Commonwealth Environmental Research Facility,

938 Charles Darwin University. Available at: http://track.gov.au/publications/registry/843.

939 Webb JA, Bond NR, Wealands SR, Mac Nally R, Quinn GP, Vesk PA, Grace MR. 2007.

940 Bayesian clustering with AutoClass explicitly recognises uncertainties in landscape

941 classification. Ecography 30: 526-536.

942 Wilstshire SE. 1986. Identification of homogeneous regions for flood frequency analysis.

$943 \quad$ Journal of Hydrology 84: 287-302. 
944 Winter TC. 2001. The concept of hydrologic landscapes. Journal of the American Water 945 Resources Association 37: 335-349.

946 Wolock DM, Winter TC, McMahon G. 2004. Delineation and evaluation of hydrologic-

947 landscape regions in the United States using geographic information system tools and

948 multivariate statistical analyses. Environmental Management 34: S71-S88.

949 Zhang Y, Xia J, Bunn SE, Arthington AH, Mackay S, Kennard M. 2011. Classification of flow

950 regimes for environmental flow assessment in regulated rivers: the Huai River Basin, China.

951 River Research and Applications, in press. DOI: 10.1002/rra.1483.

952 Zoppou C, Nielsen OM, Zhang L. 2002. Regionalization of daily stream flow in Australia using 953 wavelets and K means analysis. CMA Research Report MRR02-003, Australian National 954 University, Canberra. Available at:

955 http://wwwmaths.anu.edu.au/research.reports/mrr/02/003/ 
Table 1. Examples of deductive regionalization/classifications of environmental attributes (inferred as key determinants of riverine flow regimes). Environmental data types: Spatial Location (SL) (e.g. latitude \& longitude, catchment boundaries), Climate (C), Catchment Topography (T), Soils/Geology (SG), Vegetation (V), Flow (F), Land Use (LU). A brief description of classification methodology is also provided (see references for more details). The spatial units analyzed included individual stream segments or watersheds of varying spatial resolution with the exception of Mkandi and Kachroo (1996). All examples used gauged streamflow data to externally validate the classifications with the exception of Wolock et al. (2004).

\begin{tabular}{|l|l|l|l|l|}
\hline Scale/Location & $\begin{array}{l}\text { Environmental } \\
\text { attributes }\end{array}$ & $\begin{array}{l}\text { Geographic } \\
\text { dependence }\end{array}$ & Classification methodology & Reference(s) \\
\hline $\begin{array}{l}\text { Africa } \\
\text { (Southern) }\end{array}$ & SL, C, T, F & Dependent & $\begin{array}{l}\text { Regions delineated based on subjective interpretation of } \\
\text { environmental attributes. }\end{array}$ & Mkandi and Kachroo, 1996 \\
\hline Australia & C, T, SG, V, F & Independent & $\begin{array}{l}\text { Non-hierarchical iterative clustering method based on Gower } \\
\text { similarity of objects to groups. }\end{array}$ & $\begin{array}{l}\text { Stein et al., 2009 (see also Ward et al., } \\
\text { 2010) }\end{array}$ \\
\hline $\begin{array}{l}\text { Australia } \\
\text { (South-eastern) }\end{array}$ & SL, C, T, SG & Independent & $\begin{array}{l}\text { Clustering (using a range of similarity measures and clustering } \\
\text { methods) and Andrew's curves to identify group outliers and } \\
\text { evaluate within-group cohesiveness. }\end{array}$ & Nathan and McMahon, 1990 \\
\hline New Zealand & C, T, SG, V & Independent & $\begin{array}{l}\text { Top-down hierarchical method whereby river segments were } \\
\text { classified individually according to various differentiating } \\
\text { criteria. }\end{array}$ & $\begin{array}{l}\text { Snelder and Biggs, 2002; Snelder et } \\
\text { al., 2005 }\end{array}$ \\
\hline Scotland & C, T, SG & Independent & $\begin{array}{l}\text { Hierarchical clustering using Ward's algorithm and maximum } \\
\text { likelihood. }\end{array}$ & Acreman and Sinclair, 1986 \\
\hline USA & C, CT, SG & Independent & $\begin{array}{l}\text { Ordination (Principal Component Analysis) and clustering } \\
\text { (using a minimum variance criterion and the nearest neighbor } \\
\text { chain algorithm) }\end{array}$ & Wolock et al., 2004 \\
\hline USA (Indiana) & C, T, SG, V & Independent & $\begin{array}{l}\text { Hierarchical (single linkage, complete linkage, Ward's } \\
\text { algorithm) }{ }^{1} \text { and non-hierarchical (K-means }{ }^{1} \text {, fuzzy } \\
\text { partitioning c-means algorithm }{ }^{2} \text { clustering. }\end{array}$ & $\begin{array}{l}\text { Rao and Srinivas, 2006a }{ }^{1} \text {; Rao and } \\
\text { Srinivas, 2006b }{ }^{2}\end{array}$ \\
\hline USA (Eastern) & C, T, SG, V & Independent & $\begin{array}{l}\text { Non-hierarchical clustering using fuzzy partitioning Bayesian } \\
\text { mixture algorithm. }\end{array}$ & Sawicz et al., 2011 \\
\hline
\end{tabular}


Table 2. Examples of inductive streamflow classifications. Flow regime attributes: Magnitude (M), Frequency (F), Duration (D), Timing (T), Rate of Change (R). Temporal scale of the flow regime attributes analyzed: Daily (D), Weekly (W), Monthly (M), Annual (A). A brief description of classification methodology, instances of external validation of the classifications (i.e. using independent environmental data unless otherwise stated) and method for prediction of class membership at new locations is also provided. See references for more details and Appendix A for a complete listing of past streamflow classifications.

\begin{tabular}{|c|c|c|c|c|}
\hline Scale/Location & $\begin{array}{l}\text { Flow } \\
\text { attributes }\end{array}$ & $\begin{array}{l}\text { Temporal } \\
\text { scale }\end{array}$ & Classification methodology & Reference(s) \\
\hline \multicolumn{5}{|l|}{ Basin } \\
\hline Huai R., China & M, F, D, T & M, A & $\begin{array}{l}\text { Ordination (Principal Component Analysis), hierarchical clustering (Ward's } \\
\text { algorithm) and external validation. }\end{array}$ & Zhang et al., 2011 \\
\hline Ebro R., Spain & M, D, T & M & $\begin{array}{l}\text { Hierarchical clustering (unspecified cluster algorithm), external validation } \\
\text { and prediction (logistic regression). }\end{array}$ & Bejarano et al., 2010 \\
\hline $\begin{array}{l}\text { Missouri and } \\
\text { Yellowstone R., USA }\end{array}$ & $\mathrm{M}, \mathrm{T}$ & $\mathrm{M}, \mathrm{A}$ & Hierarchical clustering (centroid linkage). & Pegg and Pierce, 2002 \\
\hline \multicolumn{5}{|l|}{ Regional } \\
\hline Victoria, Australia & $\mathrm{M}, \mathrm{F}, \mathrm{D}, \mathrm{T}$ & $\mathrm{D}$ & $\begin{array}{l}\text { Ordination (Principal Component Analysis), hierarchical clustering (average } \\
\text { linkage) and external validation. }\end{array}$ & Hughes and James, 1989 \\
\hline Quebec, Canada & M, D, T, R & M & $\begin{array}{l}\text { Ordination (Principal Component Analysis), heuristic classification method } \\
\text { based on rules and signs of loadings on PCs and external validation. }\end{array}$ & Assani and Tardif, 2005 \\
\hline Washington, USA & $\mathrm{M}, \mathrm{F}, \mathrm{D}, \mathrm{T}, \mathrm{R}$ & $\mathrm{D}, \mathrm{M}, \mathrm{A}$ & $\begin{array}{l}\text { Non-hierarchical clustering using fuzzy partitioning Bayesian mixture } \\
\text { algorithm, external validation and prediction (random forest classifier). }\end{array}$ & $\begin{array}{l}\text { Reidy Liermann et al., } \\
2011\end{array}$ \\
\hline \multicolumn{5}{|l|}{ National/Continental } \\
\hline Australia & $\mathrm{F}, \mathrm{T}$ & $\mathrm{D}$ & Wavelet analysis and non-hierarchical clustering (K-means). & Zoppou et al., 2002 \\
\hline Australia & M, D, F, T, R & $\mathrm{D}$ & $\begin{array}{l}\text { Non-hierarchical clustering using fuzzy partitioning Bayesian mixture } \\
\text { algorithm and external validation. }\end{array}$ & Kennard et al., 2010b \\
\hline Canada & M, T & W & Hierarchical clustering (Ward's method). & Monk et al., 2011 \\
\hline France & $\mathrm{M}, \mathrm{T}$ & M & $\begin{array}{l}\text { Proportion of flow within each of four seasons, together with the source of } \\
\text { water (i.e. snow melt, glacier melt, rainfall). }\end{array}$ & Pardé, 1955 \\
\hline France & M, D, F, T, R & $\mathrm{D}$ & $\begin{array}{l}\text { Ordination (Principal Component Analysis), non-hierarchical clustering (K- } \\
\text { means), external validation and prediction (boosted regression trees). }\end{array}$ & Snelder et al., 2009a \\
\hline New Zealand & $\mathrm{M}, \mathrm{F}$ & $\mathrm{D}, \mathrm{A}$ & $\begin{array}{l}\text { Hierarchical clustering (Two-way indicator species analysis)) and external } \\
\text { validation. }\end{array}$ & Jowett and Duncan, 1990 \\
\hline
\end{tabular}




\begin{tabular}{|c|c|c|c|c|}
\hline Scale/Location & $\begin{array}{l}\text { Flow } \\
\text { attributes }\end{array}$ & $\begin{array}{l}\text { Temporal } \\
\text { scale }\end{array}$ & Classification methodology & Reference(s) \\
\hline Scandinavia & $\mathrm{M}, \mathrm{T}$ & $\mathrm{M}, \mathrm{A}$ & $\begin{array}{l}\text { Two-step approach: (1) Flow regime class discriminating criteria based on } \\
\text { the time of occurrence of the highest ( } 3 \text { classes) and lowest ( } 2 \text { classes) of } \\
\text { monthly flow, (2) entropy based groupings based on interannual variation in } \\
\text { monthly flows. }\end{array}$ & Krasovskaia, 1997 \\
\hline $\begin{array}{l}\text { South Africa, Lesotho } \\
\text { and Swaziland }\end{array}$ & $\mathrm{T}, \mathrm{M}$ & $\mathrm{M}$ & $\begin{array}{l}\text { Index of flow variability divided into classes using cumulative deviations } \\
\text { from homogeneity plots. }\end{array}$ & $\begin{array}{l}\text { Hughes and Hannart, } \\
2003\end{array}$ \\
\hline Tanzania & $\mathrm{M}, \mathrm{F}$ & A & $\begin{array}{l}\text { Three-step process: (1) Geographic information was used to identify likely } \\
\text { homogeneous regions that are geographically continuous; (2) Each region } \\
\text { was checked for similarity in the statistics of observed flood data. Based on } \\
\text { this step, regions obtained in step (1) were modified; (3) A test of } \\
\text { homogeneity was applied to confirm that the delineated regions are } \\
\text { statistically homogeneous. }\end{array}$ & Kachroo et al., 2000 \\
\hline United Kingdom & $\mathrm{M}, \mathrm{T}$ & $\mathrm{M}$ & $\begin{array}{l}\text { Hierarchical clustering (Ward's algorithm) and external validation } \\
\text { (qualitative environmental information and quantitative biological data). }\end{array}$ & Monk et al., 2006 \\
\hline United Kingdom & $\mathrm{M}, \mathrm{T}$ & $\mathrm{M}$ & $\begin{array}{l}\text { Hierarchical (Ward's algorithm) and non-hierarchical (K-means) clustering } \\
\text { and external validation. }\end{array}$ & $\begin{array}{l}\text { Bower et al., } 2004 \text { (see } \\
\text { also Harris et al., 2000; } \\
\text { Hannah et al., 2000) }\end{array}$ \\
\hline United States & $\mathrm{M}, \mathrm{F}, \mathrm{D}, \mathrm{T}$ & $\mathrm{D}, \mathrm{M}, \mathrm{A}$ & Hierarchical clustering (density linkage). & Poff, 1996 \\
\hline \multicolumn{5}{|l|}{ Global } \\
\hline & $\mathrm{M}$ & A & $\begin{array}{l}\text { Two-step approach: (1) initial groupings based on regions of similar climatic } \\
\text { conditions (based largely on Köppen's climate regions); (2) Hierarchical } \\
\text { clustering (average linkage) of stream gauges based on an index of flood } \\
\text { magnitude. }\end{array}$ & Burn and Arnell, 1993 \\
\hline & $\mathrm{M}, \mathrm{T}$ & M & Non-hierarchical clustering (K-means). & Dettinger and Diaz, 2000 \\
\hline & $\mathrm{M}, \mathrm{T}$ & $\mathrm{M}, \mathrm{A}$ & Hierarchical clustering (average linkage) and external validation. & $\begin{array}{l}\text { Haines et al., } 1988 \text { (see } \\
\text { also Finlayson and } \\
\text { McMahon, 1988) }\end{array}$ \\
\hline & $\mathrm{M}, \mathrm{F}$ & A & $\begin{array}{l}\text { Examined regional variation in mean annual flood magnitudes and flood } \\
\text { frequency curves, where regions were defined using an empirical approach } \\
\text { based firstly on physical and climatic characteristics, and second, by } \\
\text { evaluation of the homogeneity of flood frequency curves within the defined } \\
\text { regions. }\end{array}$ & Meigh et al., 1997 \\
\hline & M & M & $\begin{array}{l}\text { No actual streamflow classification but examined regional variation in } \\
\text { individual hydrologic attributes at a global scale. }\end{array}$ & McMahon et al., 2007a, b \\
\hline & M, F, D, T R & $\mathrm{D}, \mathrm{M}, \mathrm{A}$ & $\begin{array}{l}\text { Ordination (Semi Strong Hybrid Multidimensional Scaling), hierarchical } \\
\text { clustering (average linkage) and external validation. }\end{array}$ & Puckridge et al., 1998 \\
\hline
\end{tabular}




\section{FIGURE CAPTIONS}

Figure 1. Two main approaches to hydrologic classification based on deductive (environmental regionalization, hydrologic regionalization or environmental classification) and inductive (streamflow classification) reasoning.

Figure 2. Hydrologic landscape regions of the United States after Wolock et al. (2004).

Figure 3. The REC classification for New Zealand. River classes refer to a combination of climate type: warm-extremely-wet (WX), warm-wet (WW), warm-dry (WD), coolextremely-wet (CX), cool-wet (CW) and cool-dry (CD); and source of flow: glacialmountain (/GM), mountain (/M), hill (/H), low-elevation (/L) and lake (/LK). The width of the lines representing the rivers has been scaled to according to the mean flow in each river segment. Modified from Snelder et al. (2011), and provided courtesy of Ton Snelder.

Figure 4. Different components of the flow regime may be characterized over varying temporal scales for use in streamflow classifications.

Figure 5. (a) Hydrologic classification of flow-regime types for 830 stream gauges in Australia from Kennard et al. (2010b). Australian drainage divisions (thick lines) and State and Territory borders (dashed lines) are shown. (b) Inset figure shows predicted flow regime types of north-eastern Australian streams based on climate and catchment topographic characteristics and derived using a classification tree predictive model (see Kennard et al., 2010b). This figure incorporates data that are copyrighted by the Commonwealth of Australia (GeoSciences Australia, 2006). 


\section{Approaches to Hydrologic Classification}

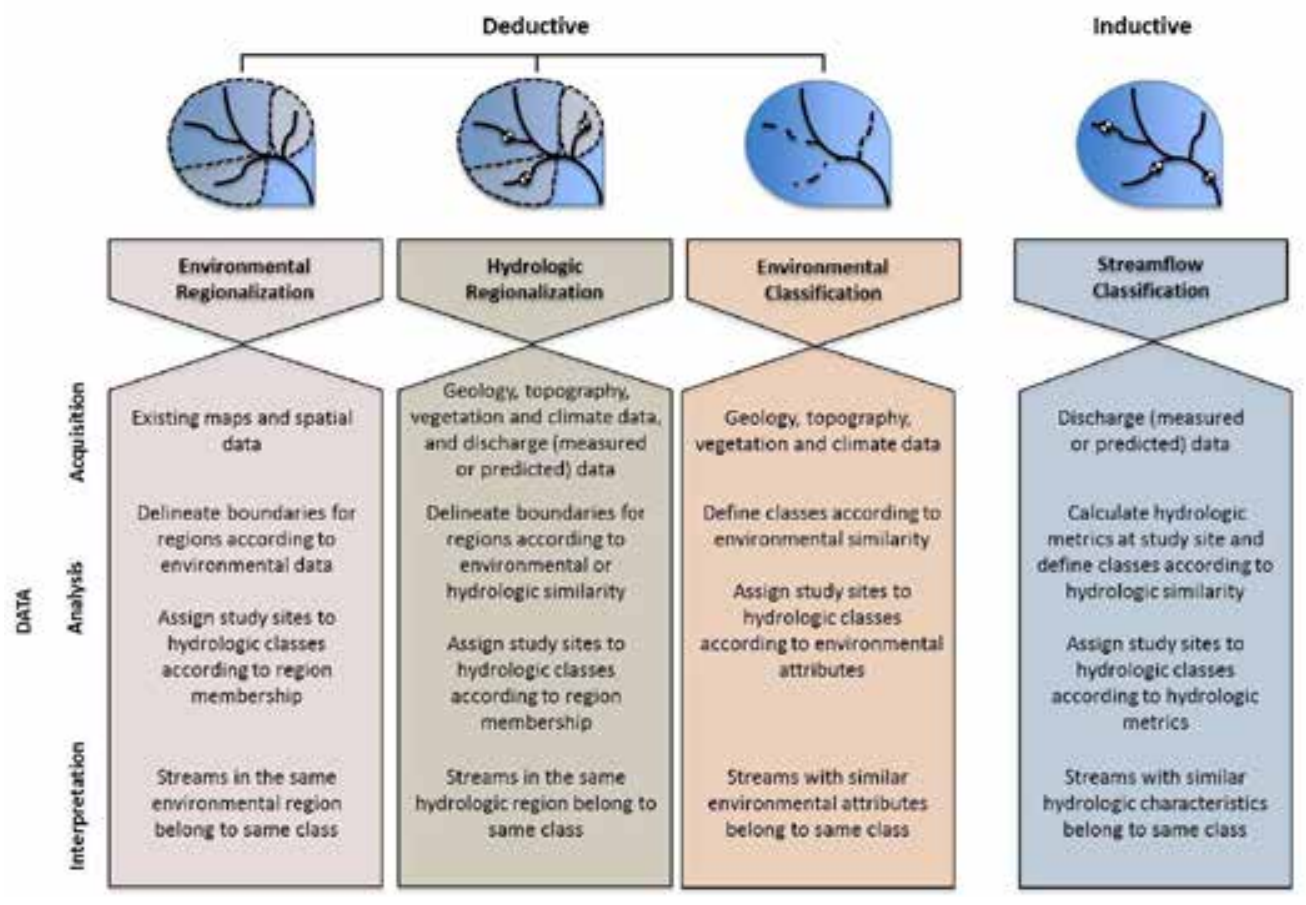




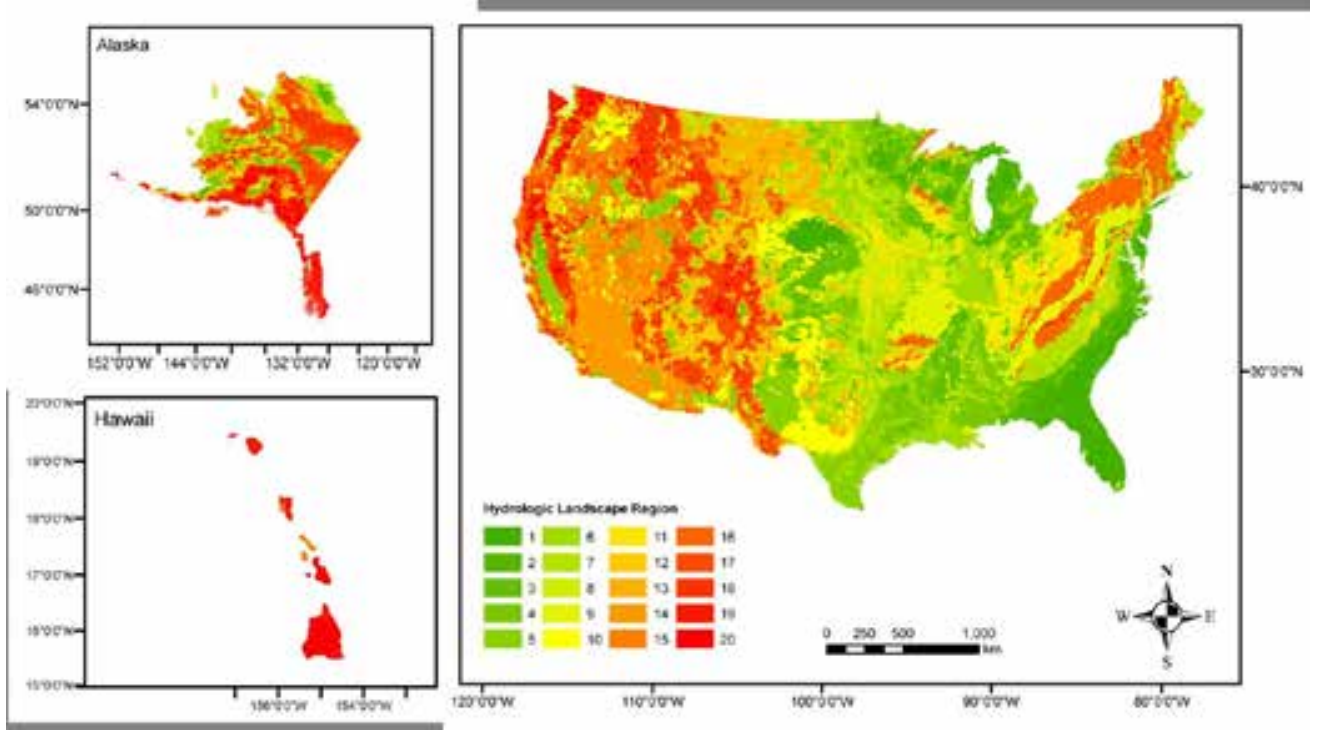




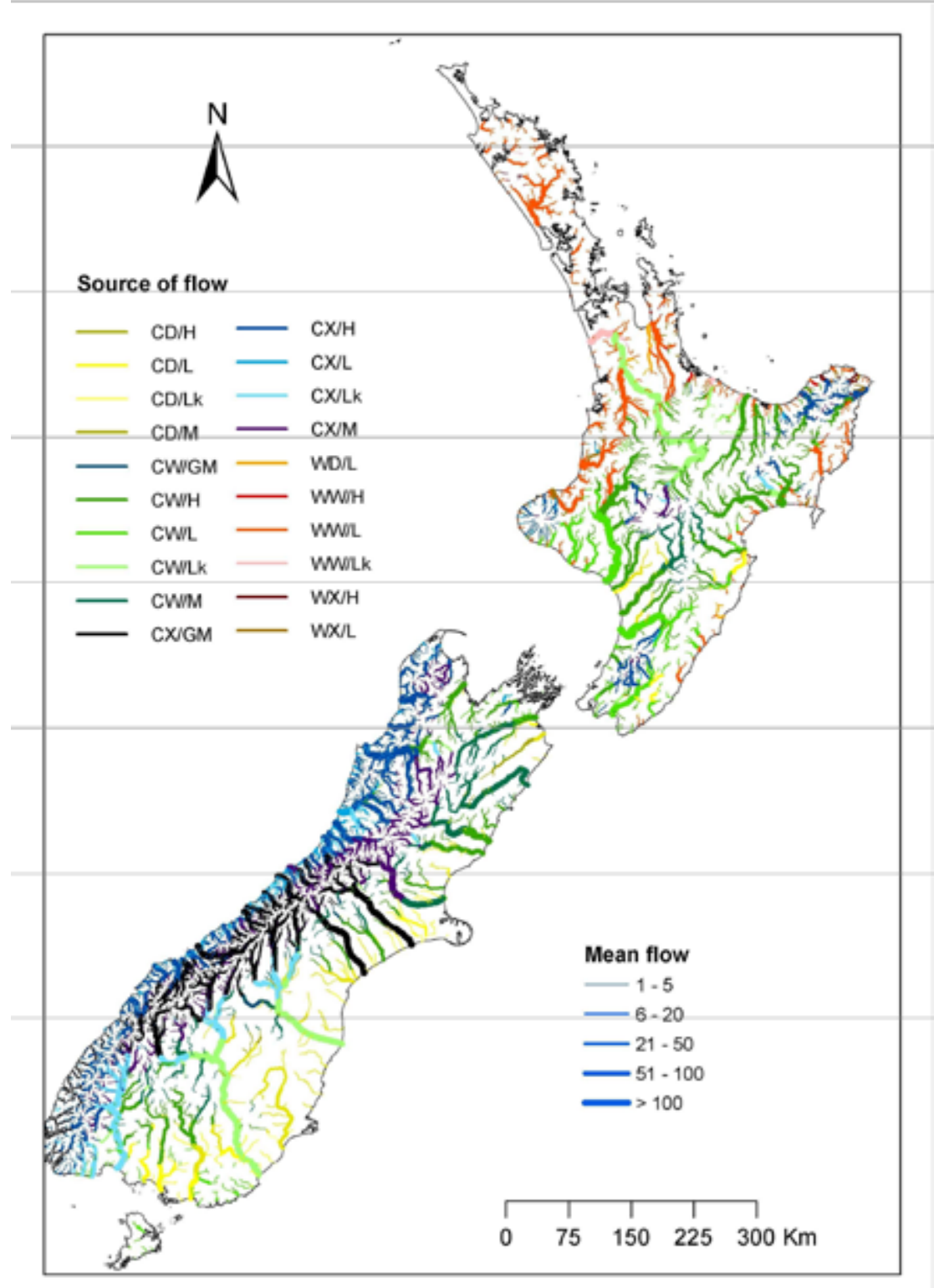




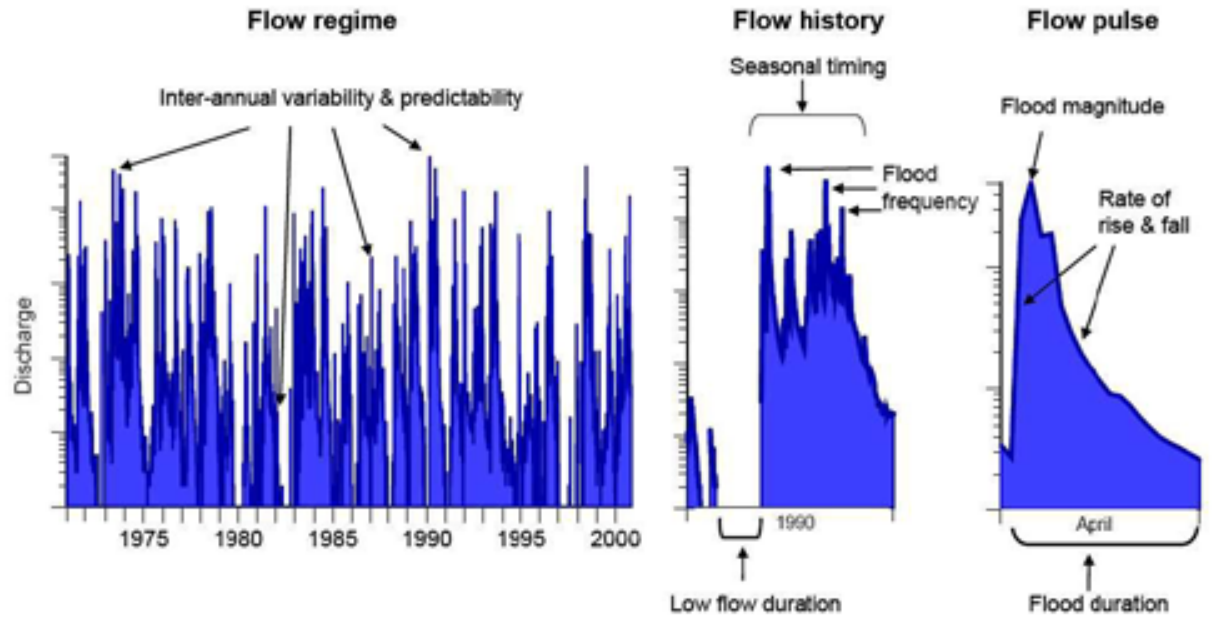




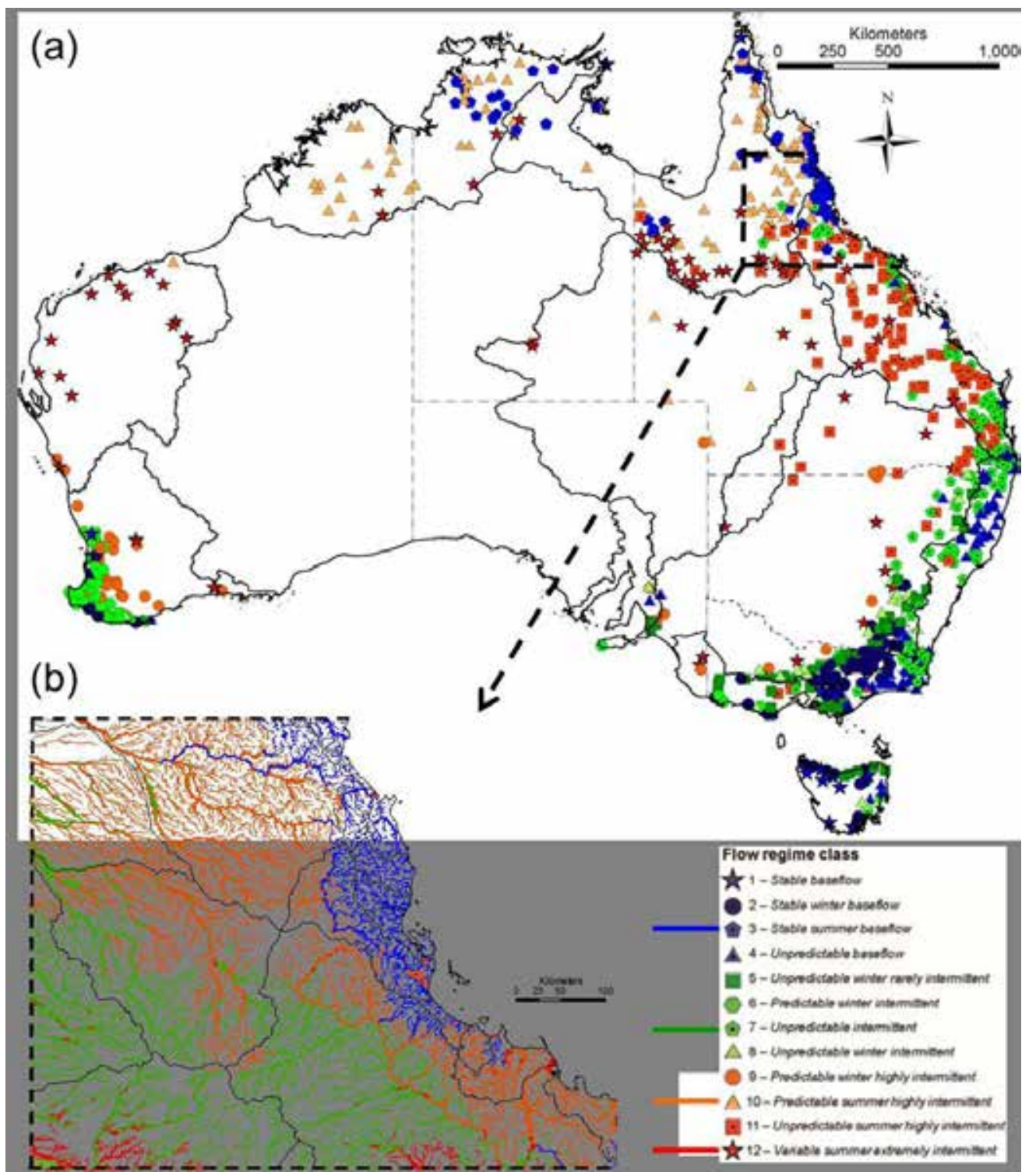


Appendix A. Examples of inductive streamflow classifications. Flow regime attributes: Magnitude (M), Frequency (F), Duration (D), Timing (T), Rate of Change (R). Temporal scale of the flow regime attributes analyzed: Daily (D), Weekly (W), Monthly (M), Annual (A). A brief description of classification methodology, instances of external validation of the classifications (i.e. using independent environmental data unless otherwise stated) and method for prediction of class membership at new locations is also provided. See references for more details.

\begin{tabular}{|c|c|c|c|c|}
\hline Scale/Location & $\begin{array}{l}\text { Flow } \\
\text { attributes }\end{array}$ & $\begin{array}{l}\text { Temporal } \\
\text { scale }\end{array}$ & Classification methodology & Reference(s) \\
\hline \multicolumn{5}{|l|}{ Basin } \\
\hline Burdekin R., Australia & M, F, D, T & $\mathrm{D}, \mathrm{M}, \mathrm{A}$ & $\begin{array}{l}\text { A-priori classification of stream gauges (based on stream size and relative } \\
\text { catchment position) and ordination (Discriminant Functions Analysis) of } \\
\text { streamflow attributes }\end{array}$ & $\begin{array}{l}\text { Pusey and } \\
\text { Arthington, } 1996\end{array}$ \\
\hline $\begin{array}{l}\text { Condamine-Balonne R., } \\
\text { Australia }\end{array}$ & $\mathrm{M}, \mathrm{F}, \mathrm{D}, \mathrm{T}, \mathrm{R}$ & $\mathrm{D}, \mathrm{M}, \mathrm{A}$ & $\begin{array}{l}\text { Ordination (Semi Strong Hybrid Multidimensional Scaling) and hierarchical } \\
\text { clustering (average linkage) }\end{array}$ & $\begin{array}{l}\text { Thoms and Parsons, } \\
2003\end{array}$ \\
\hline Huai R., China & M, F, D, T & $\mathrm{M}, \mathrm{A}$ & $\begin{array}{l}\text { Ordination (Principal Component Analysis), hierarchical clustering (Ward's } \\
\text { algorithm) and external validation }\end{array}$ & Zhang et al., 2011 \\
\hline Ebro R., Spain & $\mathrm{M}, \mathrm{D}, \mathrm{T}$ & M & $\begin{array}{l}\text { Ordination (Principal Component Analysis), hierarchical clustering (unspecified } \\
\text { cluster algorithm), external validation and prediction (logistic regression) }\end{array}$ & $\begin{array}{l}\text { Bejarano et al., } \\
2010\end{array}$ \\
\hline Tagus R., Spain & M, F, D, T & $\mathrm{D}, \mathrm{M}, \mathrm{A}$ & Hierarchical clustering (unspecified cluster algorithm) & $\begin{array}{l}\text { Baeza Sanz and } \\
\text { García del Jalón, } \\
2005\end{array}$ \\
\hline $\begin{array}{l}\text { Missouri and } \\
\text { Yellowstone R., USA }\end{array}$ & M, T & $\mathrm{M}, \mathrm{A}$ & Hierarchical clustering (centroid linkage) & $\begin{array}{l}\text { Pegg and Pierce, } \\
2002\end{array}$ \\
\hline \multicolumn{5}{|l|}{ Regional } \\
\hline Victoria, Australia & $\mathrm{M}, \mathrm{F}, \mathrm{D}, \mathrm{T}$ & $\mathrm{D}$ & $\begin{array}{l}\text { Ordination (Principal Component Analysis), hierarchical clustering (average } \\
\text { linkage) and external validation }\end{array}$ & $\begin{array}{l}\text { Hughes and James, } \\
1989\end{array}$ \\
\hline Tasmania, Australia & $\mathrm{M}, \mathrm{F}, \mathrm{D}, \mathrm{T}$ & $\mathrm{D}$ & $\begin{array}{l}\text { Ordination (Principal Coordinate Analysis), hierarchical clustering (complete } \\
\text { linkage) and external validation }\end{array}$ & Hughes, 1987 \\
\hline South-eastern Australia & $\mathrm{M}, \mathrm{D}, \mathrm{F}$ & $\mathrm{D}$ & $\begin{array}{l}\text { No actual streamflow classification but examined regional variation in flow } \\
\text { regime attributes using ordination (Semi Strong Hybrid Multidimensional } \\
\text { Scaling) }\end{array}$ & $\begin{array}{l}\text { Growns and Marsh, } \\
2000\end{array}$ \\
\hline $\begin{array}{l}\text { Gulf of Carpentaria } \\
\text { region, Australia }\end{array}$ & $\mathrm{M}, \mathrm{D}, \mathrm{F}$ & $\mathrm{D}$ & $\begin{array}{l}\text { Ordination (Semi Strong Hybrid Multidimensional Scaling) and hierarchical } \\
\text { clustering (average linkage) }\end{array}$ & $\begin{array}{l}\text { Leigh and Sheldon, } \\
2008\end{array}$ \\
\hline Quebec, Canada & $\mathrm{M}, \mathrm{D}, \mathrm{T}, \mathrm{R}$ & $\mathrm{M}$ & $\begin{array}{l}\text { Ordination (Principal Component Analysis), heuristic classification method based } \\
\text { on rules and signs of loadings on PCs and external validation }\end{array}$ & $\begin{array}{l}\text { Assani and Tardif, } \\
2005\end{array}$ \\
\hline
\end{tabular}




\begin{tabular}{|c|c|c|c|c|}
\hline Scale/Location & $\begin{array}{l}\text { Flow } \\
\text { attributes }\end{array}$ & $\begin{array}{l}\text { Temporal } \\
\text { scale }\end{array}$ & Classification methodology & Reference(s) \\
\hline Southern Taiwan & $\mathrm{M}, \mathrm{T}, \mathrm{F}$ & & Clustering and external validation (discrimination) using self-organizing maps & $\begin{array}{l}\text { Lin and Wang, } \\
2006\end{array}$ \\
\hline $\begin{array}{l}\text { Alabama, Georgia and } \\
\text { Mississippi, USA }\end{array}$ & M, T & M & $\begin{array}{l}\text { Ordination (Principal Component Analysis), hierarchical clustering (average } \\
\text { linkage) and external validation }\end{array}$ & $\begin{array}{l}\text { Chiang et al., } \\
\text { 2002a,b }\end{array}$ \\
\hline $\begin{array}{l}\text { Arizona, New Jersey, } \\
\text { Pennsylvania, Texas, } \\
\text { USA }\end{array}$ & M, F & $\mathrm{D}, \mathrm{A}$ & Hierarchical clustering (complete linkage) and external validation & Tasker, 1982 \\
\hline \multicolumn{5}{|l|}{ National/Continental } \\
\hline Australia & $\mathrm{M}, \mathrm{D}, \mathrm{F}, \mathrm{T}, \mathrm{R}$ & $\mathrm{D}$ & $\begin{array}{l}\text { Non-hierarchical clustering using fuzzy partitioning Bayesian mixture algorithm } \\
\text { and external validation }\end{array}$ & $\begin{array}{l}\text { Kennard et al., } \\
\text { 2010b }\end{array}$ \\
\hline Australia & $\mathrm{F}, \mathrm{T}$ & $\mathrm{D}$ & Wavelet analysis and non-hierarchical clustering (K-means) & Zoppou et al., 2002 \\
\hline Austria & M, T & $\mathrm{D}$ & $\begin{array}{l}\text { Ordination (Principal Component Analysis), non-hierarchical clustering (K- } \\
\text { medoids) and external validation }\end{array}$ & $\begin{array}{l}\text { Laaha and Blöschl, } \\
2006\end{array}$ \\
\hline Canada & M, T & $\mathrm{W}$ & Hierarchical clustering (Ward's method) & Monk et al., 2011 \\
\hline France & M, T & M & $\begin{array}{l}\text { Proportion of flow within each of four seasons, together with the source of water } \\
\text { (i.e. snow melt, glacier melt, rainfall) }\end{array}$ & Parde, 1955 \\
\hline France & M, D, F, T, R & $\mathrm{D}$ & $\begin{array}{l}\text { Ordination (Principal Component Analysis), non-hierarchical clustering (K- } \\
\text { means), external validation and prediction (boosted regression trees) }\end{array}$ & $\begin{array}{l}\text { Snelder et al., } \\
\text { 2009a }\end{array}$ \\
\hline $\begin{array}{l}\text { Mediterranean countries } \\
\text { (Portugal, France, Italy, } \\
\text { Cyprus, Morocco, } \\
\text { Algeria, Tunisia, Israel) }\end{array}$ & M, D, F, T, R & $\mathrm{D}, \mathrm{M}, \mathrm{A}$ & $\begin{array}{l}\text { Ordination (Principal Components Analysis), hierarchical clustering (group } \\
\text { average) and external validation }\end{array}$ & Oueslati et al., 2010 \\
\hline Nepal & M, T & M & Hierarchical clustering (Ward's algorithm) & $\begin{array}{l}\text { Hannah et al., } 2005 \\
\text { (see also Harris et } \\
\text { al., 2000; Hannah } \\
\text { et al., 2000; Bower } \\
\text { et al., 2004) }\end{array}$ \\
\hline New Zealand & $\mathrm{M}$ & $\mathrm{D}$ & Hierarchical clustering (Ward's algorithm ) & Mosley, 1981 \\
\hline New Zealand & M, F & $\mathrm{D}, \mathrm{A}$ & $\begin{array}{l}\text { Hierarchical clustering (Two-way indicator species analysis) and external } \\
\text { validation }\end{array}$ & $\begin{array}{l}\text { Jowett and Duncan, } \\
1990\end{array}$ \\
\hline New Zealand & $\mathrm{M}, \mathrm{F}, \mathrm{D}, \mathrm{T}, \mathrm{R}$ & $\mathrm{D}$ & Hierarchical clustering (flexible beta) & Snelder et al., 2005 \\
\hline Russia & M, T & M & $\begin{array}{l}\text { Proportion of flow within each of four seasons, together with the source of water } \\
\text { (i.e. snow melt, glacier melt, rainfall and groundwater) }\end{array}$ & Lvovich, 1973 \\
\hline
\end{tabular}




\begin{tabular}{|c|c|c|c|c|}
\hline Scale/Location & $\begin{array}{l}\text { Flow } \\
\text { attributes }\end{array}$ & $\begin{array}{l}\text { Temporal } \\
\text { scale }\end{array}$ & Classification methodology & Reference(s) \\
\hline Scandinavia & M, T & M & $\begin{array}{l}\text { Flow regime class discriminating criteria based on the time of occurrence of the } \\
\text { highest ( } 3 \text { classes) and lowest ( } 2 \text { classes) of mean monthly flow }\end{array}$ & $\begin{array}{l}\text { Gottschalk et al., } \\
\text { 1979; Krasovskaia } \\
\text { and Gottschalk, } \\
2002\end{array}$ \\
\hline Scandinavia & M, T & $\mathrm{M}, \mathrm{A}$ & $\begin{array}{l}\text { Two-step approach: (1) Flow regime class discriminating criteria based on the } \\
\text { time of occurrence of the highest ( } 3 \text { classes) and lowest ( } 2 \text { classes) of monthly } \\
\text { flow, (2) entropy based groupings based on interannual variation in monthly } \\
\text { flows }\end{array}$ & Krasovskaia, 1997 \\
\hline $\begin{array}{l}\text { Scandinavia and western } \\
\text { Europe }\end{array}$ & M, T & M & $\begin{array}{l}\text { Flow regime class discriminating criteria based on the time of occurrence of the } \\
\text { highest ( } 3 \text { classes) and lowest ( } 2 \text { classes) of mean monthly flow }\end{array}$ & Krasovskaia, 1995 \\
\hline $\begin{array}{l}\text { South Africa, Lesotho } \\
\text { and Swaziland }\end{array}$ & $\mathrm{T}, \mathrm{M}$ & M & $\begin{array}{l}\text { Index of flow variability divided into classes using cumulative deviations from } \\
\text { homogeneity plots }\end{array}$ & $\begin{array}{l}\text { Hughes and } \\
\text { Hannart, } 2003\end{array}$ \\
\hline Sweden & M, T & M & $\begin{array}{l}\text { Ordination (Principal Component Analysis) and hierarchical clustering (average } \\
\text { linkage) }\end{array}$ & Gottschalk, 1985 \\
\hline Taiwan & M, D, F, R & $\mathrm{D}$ & Non-hierarchical clustering (K-means) and self-organizing maps & Chang et al., 2008 \\
\hline Tanzania & $\mathrm{M}, \mathrm{F}$ & A & $\begin{array}{l}\text { Three-step process: (1) Geographic information was used to identify likely } \\
\text { homogeneous regions that are geographically continuous; (2) Each region was } \\
\text { checked for similarity in the statistics of observed flood data. Based on this step, } \\
\text { regions obtained in step (1) were modified; (3) A test of homogeneity was applied } \\
\text { to confirm that the delineated regions are statistically homogeneous }\end{array}$ & $\begin{array}{l}\text { Kachroo et al., } \\
2000\end{array}$ \\
\hline Turkey & M & A & Non-hierarchical clustering (K-means) & Kayha et al., 2007 \\
\hline United Kingdom & M, T & M & $\begin{array}{l}\text { Hierarchical clustering (Ward's algorithm) and external validation (qualitative } \\
\text { environmental information and quantitative biological data) }\end{array}$ & Monk et al., 2006 \\
\hline United Kingdom & M, T & M & Hierarchical clustering (average linkage) & $\begin{array}{l}\text { Harris et al., } 2000 \\
\text { (see also Hannah et } \\
\text { al., 2000) }\end{array}$ \\
\hline United Kingdom & M, T & M & $\begin{array}{l}\text { Hierarchical (Ward's algorithm) and non-hierarchical (K-means) clustering and } \\
\text { external validation }\end{array}$ & $\begin{array}{l}\text { Bower et al., } 2004 \\
\text { (see also Harris et } \\
\text { al., 2000; Hannah } \\
\text { et al., 2000) }\end{array}$ \\
\hline $\begin{array}{l}\text { United Kingdom (and } \\
\text { other regions) }\end{array}$ & M, T, F, D & & Hierarchical clustering (Ward's algorithm) and external validation & Stahl, 2001 \\
\hline United States & M, T & $\mathrm{Y}$ & $\begin{array}{l}\text { No actual streamflow classification but examined regional variation in flow } \\
\text { regime attributes using ordination (Principal Component Analysis) }\end{array}$ & Lins, 1985 \\
\hline United States & M, F, D, T & $\mathrm{D}, \mathrm{M}, \mathrm{A}$ & Non-hierarchical clustering (K-means) and external validation & $\begin{array}{l}\text { Poff and Ward, } \\
1989\end{array}$ \\
\hline United States & $\mathrm{M}, \mathrm{F}, \mathrm{D}, \mathrm{T}$ & $\mathrm{D}, \mathrm{M}, \mathrm{A}$ & Hierarchical clustering (density linkage) & Poff, 1996 \\
\hline
\end{tabular}




\begin{tabular}{|c|c|c|c|c|}
\hline Scale/Location & $\begin{array}{l}\text { Flow } \\
\text { attributes }\end{array}$ & $\begin{array}{l}\text { Temporal } \\
\text { scale }\end{array}$ & Classification methodology & Reference(s) \\
\hline \multicolumn{5}{|l|}{ Global } \\
\hline & M & A & $\begin{array}{l}\text { Two-step approach: (1) initial groupings based on regions of similar climatic } \\
\text { conditions (based largely on Köppen's climate regions); (2) Hierarchical } \\
\text { clustering (average linkage) of stream gauges based on an index of flood } \\
\text { magnitude }\end{array}$ & $\begin{array}{l}\text { Burn and Arnell, } \\
1993\end{array}$ \\
\hline & $\mathrm{M}, \mathrm{T}$ & M & Non-hierarchical clustering (K-means) & $\begin{array}{l}\text { Dettinger and Diaz, } \\
2000\end{array}$ \\
\hline & $\mathrm{M}, \mathrm{T}$ & M & Hierarchical clustering (average linkage) & $\begin{array}{l}\text { Finlayson and } \\
\text { McMahon, } 1988\end{array}$ \\
\hline & $\mathrm{M}, \mathrm{T}$ & M, A & Hierarchical clustering (average linkage) and external validation & Haines et al., 1988 \\
\hline & $\mathrm{M}, \mathrm{F}$ & A & $\begin{array}{l}\text { Examined regional variation in mean annual flood magnitudes and flood } \\
\text { frequency curves, where regions were defined using an empirical approach based } \\
\text { firstly on physical and climatic characteristics, and second, by evaluation of the } \\
\text { homogeneity of flood frequency curves within the defined regions. }\end{array}$ & Meigh et al., 1997 \\
\hline & M & M & $\begin{array}{l}\text { No actual streamflow classification but examined regional variation in individual } \\
\text { hydrologic attributes at a global scale }\end{array}$ & $\begin{array}{l}\text { McMahon et al., } \\
2007\end{array}$ \\
\hline & M, F, D, T R & $\mathrm{D}, \mathrm{M}, \mathrm{A}$ & $\begin{array}{l}\text { Ordination (Semi Strong Hybrid Multidimensional Scaling), hierarchical } \\
\text { clustering (average linkage) and external validation }\end{array}$ & $\begin{array}{l}\text { Puckridge et al., } \\
1998\end{array}$ \\
\hline
\end{tabular}

\section{References}

Assani AA, Tardif S. 2005. Classification and characterization of natural flow regimes in Quebec (Canada). Factors of spatial variability - an eco-geographical approach. Revue Des Sciences De L'Eua 18: 247-266.

Baeza Sanz D, García del Jalón D. 2005. Characterisation of streamflow regimes in central Spain, based on relevant hydrobiological parameters. Journal of Hydrology 310: 266-279.

Bejarano MD, Marchamalo M, de Jalón DG, Tánago MG. 2010. Flow regime patterns and their controlling factors in the Ebro basin (Spain). Journal of Hydrology 385: 323-335.

Bower D, Hannah DM, McGregor GR. 2004. Techniques for assessing the climatic sensitivity of river flow regimes. Hydrological

Processes 18: 2515-2543. 
Chang FJ, Tsai MJ, Tsai WP, Herricks EE. 2008. Assessing the ecological hydrology of natural flow conditions in Taiwan. Journal of Hydrology 354: 75-89.

Chiang SM, Tsay TK, Nix SJ. 2002a. Hydrologic regionalization of watersheds. I: Methodology development. Journal of Water Resources Planning and Management 128: 3-11.

Chiang SM, Tsay TK, Nix SJ. 2002b. Hydrologic regionalization of watersheds. II: Applications. Journal of Water Resources Planning and Management 128: 12-20.

Dettinger MD, Diaz HF. 2000. Global characteristics of stream flow seasonality and variability. Journal of Hydrometeorology 1: 289310.

Finlayson BL, McMahon TA. 1988. Australia vs. the World: A comparative analysis of streamflow characteristics. Pp 17-40 In: Werner RF (ed.), Fluvial Geomorphology of Australia, Academic Press, Sydney.

Gottschalk L, Lundager J, Lundquist D, Solantie R, Tollan A. 1979. Hydrologic regions in the Nordic countries. Nordic Hydrology 10: 273-286.

Gottschalk L. 1985. Hydrological regionalization of Sweden. Hydrological Science 30: 65-83.

Growns J, Marsh N. 2000. Characterisation of flow in regulated and unregulated streams in eastern Australia. Technical Report, Cooperative Research Centre for Freshwater Ecology. 66 pp.

Haines AT, Findlayson BL, McMahon TA. 1988. A global classification of river regimes. Applied Geography 8: $255-272$.

Hannah DM, Smith BPG, Gurnell AM, McGregor GR. 2000. An approach to hydrograph classification. Hydrological Processes 14: 317-338.

Hannah DM, Kansakar SR, Gerrard AJ, Rees G. 2005. Flow regimes of Himalayan rivers of Nepal: nature and spatial patterns. Journal of Hydrology 308: 18-32.

Harris NM, Gurnell AM, Hannah DM, Petts GE. 2000. Classification of river regimes: a context for hydroecology. Hydrological Processes 14: 2831-2848. 
Hughes DA, Hannart P. 2003. A desktop model used to provide an initial estimate of the ecological instream flow requirements of rivers in South Africa. Journal of Hydrology 270: 167-181.

Hughes JMR. 1987. Hydrological characteristics and classification of Tasmanian rivers. Australian Geographical Studies 25: 61-82.

Hughes JMR, James B. 1989. A hydrological regionalization of streams in Victoria, Australia, with implications for stream ecology. Australian Journal of Marine and Freshwater Resources 40: 303-326.

Jowett IG, Duncan MJ. 1990. Flow variability in New Zealand rivers and its relationship to in-stream habitat and biota. New Zealand Journal of Marine and Freshwater Research 24: 305-317.

Kachroo RK, Mkhandi SH. 2000. Flood frequency analysis of southern Africa: I. Delineation of homogeneous regions. Hydrological Science 45: 437-447.

Kahya E, Demirel MC, Piechota TC. 2007. Spatial grouping of annual streamflow patterns in Turkey. Paper presented at Hydrology Days, Colorado State Univ. (Available at: http://hydrologydays.colostate.edu/Papers_2007/Demirel_Kahya_paper.pdf).

Kennard MJ, Pusey BJ, Olden JD, Mackay SJ, Stein JL, Marsh N. 2010b. Classification of natural flow regimes in Australia to support environmental flow management. Freshwater Biology 55: 171-193.

Krasovskaia I. 1995. Quantification of the stability of river flow regimes. Hydrological Science 40: 587-598.

Krasovskaia I. 1997. Entropy-based grouping of river flow regimes. Journal of Hydrology 202: 173-191.

Krasovskaia I, Gottschalk L. 2002. River flow regimes in a changing climate. Hydrological Science 47: $597-609$.

Laaha G, Blöschl G. 2006. A comparison of low flow regionalization methods - catchment grouping. Journal of Hydrology 323: 193214.

Leigh C, Sheldon F. 2008. Hydrological changes and ecological impacts associated with water resource development in large floodplain rivers in the Australian tropics. River Research and Applications 24: 1251-1270

Lin G-F, Wang C-M. 2006. Performing cluster analysis and discrimination analysis of hydrological factors in one step. Advances Water Research 29: 1573-1585. 
Lins HF. 1985. Streamflow variability in the United States: 1931-78. Journal of Climate Applications and Meteorology 24: $463-471$.

Lvovich MI. 1973. The World's Water. Mir, Moscow, 213 pp.

McMahon TA, Vogel RM, Peel MC, Pegram GGS. 2007. Global streamflows - Part 1: Characteristics of annual streamflows. Journal of Hydrology 347: 243-259

Meigh JR, Farquharson FAK, Sutcliffe JV. 1997. A worldwide comparison of regional flood estimation methods and climate.

Hydrology Science 42: 225-244.

Monk WA, Peters DL, Curry RA, Baird DJ. 2011. Quantifying trends in indicator hydroecological variables for regime-based groups of Canadian river. Hydrological Processes, in press. DOI: 10.1002/hyp.8137.

Monk WA, Wood PJ, Hannah DM, Wilson DA, Extence CA, Chadd RP. 2006. Flow variability and macroinvertebrate community response within riverine systems. River Research and Applications 22: 595-615.Mosley MP. 1981. Delimitation of New Zealand hydrologic regions. Journal of Hydrology 49: 179-192.

Oueslati O, De Girolamo AM., Abouabdillah A, Lo Porto A. 2010. Attempts to flow regime classification and characterisation in Mediterranean streams using multivariate analysis. Advances in Statistical Hydrology, International Workshop Proceedings, May 23-25, 2010 Taormina, Italy.

Parde M. 1955. Fleuves et rivieres. Collection Armand Colin, Paris, 224 pp.

Pegg MA, Pierce CL. 2002. Classification of reaches in the Missouri and lower Yellowstone rivers based on flow characteristics. River Research and Applications 18: 31-42.

Poff NL. 1996. A hydrogeography of unregulated streams in the United States and an examination of scale-dependence in some hydrological descriptors. Freshwater Biology 36: 71-91.

Poff NL, Ward JV. 1989. Implications of streamflow variability and predictability for lotic community structure: a regional analysis of streamflow patterns. Canadian Journal of Fisheries and Aquatic Sciences 46: 1805-1818. 
Puckridge JT, Sheldon F, Walker KF, Boulton AJ. 1998. Flow variability and the ecology of large rivers. Marine and Freshwater Research 49: 55-72.

Pusey BJ, Arthington AH. 1996. Streamflow variability within the Burdekin River. Proceedings of the 23rd Hydrology and Water Resources Symposium. Pp. 213-220. Australian Institute of Engineers, Barton.

Snelder TH, Biggs BJF, Woods RA. 2005. Improved eco-hydrological classification of rivers. River Research and Applications 21: 609-628.

Snelder TH, Lamouroux N, Leathwick JR, Pella H, Sauquet E, Shankar U. 2009a. Predictive mapping of the natural flow regimes of France. Journal of Hydrology 373: 56-67.

Stahl K. 2001. Hydrological drought: A study across Europe. PhD Dissertation, Albert Ludwig University, Freiburg, Germany. Tasker GD. 1982. Comparing methods of hydrologic regionalization. Water Resources Bulletin 18: 965-970.

Thoms MC, Parsons M. 2003. Identifying spatial and temporal patterns in the hydrological character of the Conadmine-Balonne river, Australia, using multivariate statistics. River Research and Applications 19: 443-457.

Zhang Y, Xia J, Bunn SE, Arthington AH, Mackay S, Kennard M. 2011. Classification of flow regimes for environmental flow assessment in regulated rivers: the Huai River Basin, China. River Research and Applications DOI: 10.1002/rra.1483.

Zoppou C, Nielsen OM, Zhang L. 2002. Regionalization of daily stream flow in Australia using wavelets and K means analysis. CMA Research Report MRR02-003, Australian National University, Canberra. Available at: http://wwwmaths.anu.edu.au/research.reports/mrr/02/003/ 